\title{
Differential effects of Th I, monocyte/macrophage and Th2 cytokine mixtures on early gene expression for molecules associated with metabolism, signaling and regulation in central nervous system mixed glial cell cultures
}

\author{
Robert P Lisak ${ }^{1,2}$, Joyce A Benjamins*1,2,3, Beverly Bealmear ${ }^{1}$, \\ Liljana Nedelkoska1, Diane Studzinski1 ${ }^{1,6,7}$, Ernest Retland ${ }^{1}$, Bin Yao ${ }^{4,5}$ and \\ Susan Land ${ }^{4,5}$
}

\begin{abstract}
Address: ${ }^{1}$ Department of Neurology, 8D University Health Center, Wayne State University School of Medicine, 4201 St Antoine, Detroit, MI, 48210, USA, ${ }^{2}$ Department of Immunology and Microbiology, Wayne State University School of Medicine, 540 E Canfield Avenue, Detroit, MI 48201, USA, ${ }^{3}$ Department of Biochemistry and Molecular Biology, Wayne State University School of Medicine, 540 E Canfield Avenue, Detroit, MI 48201, USA, ${ }^{4}$ Applied Genomics Technology Center, 5107 Biological Sciences, Wayne State University, 5047 Gullen Mall, Detroit MI 48202 , USA, ${ }^{5}$ Center for Molecular Medicine and Genetics, Wayne State University School of Medicine, 540 E Canfield, Detroit, MI 48201, USA,

${ }^{6}$ Department of Surgery, 6C University Health Center, Wayne State University School of Medicine, 4201 St Antoine, Detroit MI, US 48201, USA and ${ }^{7}$ Department of Surgery, William Beaumont Hospital, 3601 W Thirteen Mile Rd, Royal Oak MI 48073, USA
\end{abstract}

Email: Robert P Lisak - rlisak@med.wayne.edu; Joyce A Benjamins* - jbenjami@med.wayne.edu;

Beverly Bealmear - bbealmea@med.wayne.edu; Liljana Nedelkoska - aa8929@wayne.edu; Diane Studzinski - dstudzin@med.wayne.edu; Ernest Retland - eretland@med.wayne.edu; Bin Yao - yaob@hotmail.com; Susan Land - sland@med.wayne.edu

* Corresponding author

Published: 21 January 2009

Journal of Neuroinflammation 2009, 6:4 doi:10.1 186/1742-2094-6-4
Received: I August 2008

Accepted: 21 January 2009

This article is available from: http://www.jneuroinflammation.com/content/6/1/4

(c) 2009 Lisak et al; licensee BioMed Central Ltd.

This is an Open Access article distributed under the terms of the Creative Commons Attribution License (http://creativecommons.org/licenses/by/2.0), which permits unrestricted use, distribution, and reproduction in any medium, provided the original work is properly cited.

\begin{abstract}
Background: Cytokines secreted by immune cells and activated glia play central roles in both the pathogenesis of and protection from damage to the central nervous system (CNS) in multiple sclerosis (MS).

Methods: We have used gene array analysis to identify the initial direct effects of cytokines on CNS glia by comparing changes in early gene expression in CNS glial cultures treated for 6 hours with cytokines typical of those secreted by ThI and Th2 lymphocytes and monocyte/macrophages (M/M).

Results: In two previous papers, we summarized effects of these cytokines on immune-related molecules, and on neural and glial related proteins, including neurotrophins, growth factors and structural proteins. In this paper, we present the effects of the cytokines on molecules involved in metabolism, signaling and regulatory mechanisms in CNS glia. Many of the changes in gene expression were similar to those seen in ischemic preconditioning and in early inflammatory lesions in experimental autoimmune encephalomyelitis (EAE), related to ion homeostasis, mitochondrial function, neurotransmission, vitamin $D$ metabolism and a variety of transcription factors and signaling pathways. Among the most prominent changes, all three cytokine mixtures markedly downregulated the dopamine D3 receptor, while Th1 and Th2 cytokines downregulated neuropeptide $Y$ receptor 5 . An unexpected finding was the large number of changes related to lipid metabolism, including several suggesting a switch from diacylglycerol to phosphatidyl inositol
\end{abstract}


mediated signaling pathways. Using QRT-PCR we validated the results for regulation of genes for iNOS, arginase and $\mathrm{P}$ glycoprotein/multi-drug resistance protein I (MDRI) seen at 6 hours with microarray.

Conclusion: Each of the three cytokine mixtures differentially regulated gene expression related to metabolism and signaling that may play roles in the pathogenesis of MS, most notably with regard to mitochondrial function and neurotransmitter signaling in glia.

\section{Background}

Genomic analysis has been applied to investigate changes occurring in the central nervous system (CNS) in multiple sclerosis (MS). These include analyses of acute and chronic active lesions, lesions from patients at different stages of MS, and comparisons of normal appearing white matter (NAWM) and normal appearing gray matter (NAGM). Examination of changes in the lesions themselves showed numerous changes in genes related to immune and stress responses, as might be predicted from the pathologic changes in lesions [1-6]. Based on the premise that some of the earliest changes in the pathogenesis of MS lesions would be found in NAWM, where infiltration of immune cells is much less prominent $[7,8]$, Graumann and colleagues [9] analyzed genomic changes in NAWM from patients with secondary progressive MS (SPMS), and found evidence for changes characteristic of neuroprotective mechanisms initially identified in ischemic preconditioning associated with hypoxic insult. Dutta et al [10] examined NAGM and identified reduced expression of nuclear-encoded mitochondrial genes, as well as in genes related to ion homeostasis and neurotransmission. Several of the changes could be localized to neurons but since glia comprise a large proportion of the tissue samples, the relative contribution of neurons and glia to the changes in gene expression could not be quantitated. More recently the same group found upregulation of genes and proteins associated with ciliary neurotrophic factor (CNTF) and signaling pathways in normal cortical gray matter [11]. Subsequently, Mahad, et al [12] found decreased expression of mitochondrial Complex IV cytochrome oxidase subunits COX I and COX IV in type III MS lesions, suggesting that the hypoxia-like damage in this type of lesion may result from mitochondrial dysfunction. These findings suggest that a wide range of metabolic changes occur in both neurons and glia throughout the MS brain, independent of the local presence of systemic inflammatory cells, and that secretory products of immune cells and activated glia may play central roles in the pathogenesis of and protection from both white matter and gray matter damage in MS.

To dissect the underlying molecular changes that might occur in glial cells exposed to secreted products of immune cells, we are utilizing gene array analysis to compare the early effects of mixtures of cytokines typical of Th1 cells, monocyte/macrophages (M/M) or Th2 cells on gene transcription in cultures of mixed CNS glia from rat brain. We have initially focused on changes in gene expression at 6 hours of exposure of CNS glia to cytokines to identify some of the earliest primary responses that might occur in MS brains in response to cytokines, without the confound of changes in gene expression in the inflammatory cells, especially those regulated in the Th1 and Th2 cells. We are currently examining several of the changes in glial cell gene expression by quantitative real time-polymerase chain reaction (QRT-PCR) to analyze the duration of the effects, and find that some changes persist for as long as 5 days $[13,14]$. In two previous papers, we summarized the effects of these cytokine mixtures on immune-related molecules [15] and on neural and glial related proteins, including neurotrophins, growth factors and structural proteins [16]. Each of the cytokine mixtures induced an unique and complex pattern of changes after 6 hours of incubation. In this third paper, we present the effects of the Th1, M/M and Th2 cytokine mixtures on early gene expression ( 6 hours) for molecules involved in metabolism, signaling and regulatory mechanisms in CNS glia. A number of the changes found are similar to those found in a gene array analysis of changes in rat spinal cord during the course of myelin basic protein (MBP)-induced experimental autoimmune encephalomyelitis (EAE) [17], including changes in ion homeostasis, mitochondrial function, neurotransmitterrelated enzymes, and a variety of signaling pathways. An unexpected finding was the large number of changes in early gene expression related to lipid metabolism.

The culture system we have analyzed is devoid of neurons to enable identification of the responses of the several types of glia to the cytokines in the absence of cross talk with neuronal signaling. For example, although classically thought of as neuron specific, neurotransmitter receptors on glial cells are now known to play prominent roles in glial differentiation [18-22], axonal/neuronal protection [21-26], microglial activation [23] and impulse conduction along myelinated axons [24]. We are initiating studies on enriched neuronal cultures to identify the direct 
effects of the three cytokine mixtures on early gene expression in neurons for comparison with the changes found in glia, with the goal of identifying those cytokines most supportive of preventing damage and promoting normal axonal function.

\section{Methods}

The methodology has been described in detail in the prior papers $[15,16]$.

\section{Mixed CNS glial cell cultures}

Mixed CNS glial cell cultures were obtained from neonatal rat brain using a modification of the so-called "shake-off" technique $[25,26]$ as we described previously [27]. Following shakeoff of cells from the astroglial bed layer, the time for partial removal of microglia by adherence to plastic was 1 hour prior to plating on poly-lysine coated flasks. Cells were maintained in defined medium containing 2\% fetal bovine serum for 6-8 days, then treated with the cytokines. The composition of cultures was examined by indirect immunofluorescence (IF) with antibodies to phenotypic markers for different cells types: glial acidic fibrillary protein (GFAP) for astrocytes [28] (Chemicon, Temecula, CA); galactolipids (GalL) for oligodendrocytes $[28,29]$; A2B5 for oligodendrocyte precursors [30] (ATCC, Bethesda, MD); ED-1 for microglia [31] (Serotec, Raleigh, NC), Thy1.1 for fibroblasts [32] and in glial cultures some astrocytes [33]; anti-neurofilament heavy chain (NFh) for neurons [34] and anti-factor VIII for endothelial cells (Dako Corporation, Carpinteria, CA).

\section{Cytokine mixtures}

The Th1 cytokine mixture included the rat recombinant cytokines interleukin-2 (IL-2), interferon- $\gamma($ IFN- $\gamma)($ R\&D Systems, Inc, Minneapolis), tumor necrosis factor- $\alpha$ (TNF$\alpha$; BD PharMigen, San Diego, CA) and mouse granulocyte-colony stimulating factor (G-CSF; PeproTech, Rocky Hill, NJ).

The $\mathrm{M} / \mathrm{M}$ cytokine mixture included the rat recombinant cytokines IL- $1 \alpha$ and IL-1 $\beta$, IL-6, IL-12p40 (all from R\&D Systems, Inc) and TNF- $\alpha$. These cytokines would be considered proinflammatory products of $\mathrm{M} 1$ macrophages or microglia [35].

The Th2 cytokine mixture included the rat recombinant cytokines IL-4, IL-5, and IL-10 (all from R\&D Systems, Inc), mouse G-CSF and purified porcine transforming growth factor- $\beta 1$ (TGF- $\beta 1$; R\&D Systems, Inc.). In the cognate immune system, in some species, TGF- $\beta 1$ is considered by some to be the product of so-called Th 3 cells. TGF- $\beta 1$ is also important in the development of another population of $\mathrm{T}$ cells called regulatory T-cells (Treg cells) which are phenotypically characterized as CD4+/CD25 high+/Fox3 [36,37]. These Treg cells may also secrete TGF- $\beta 1$.
Cytokine mixtures contained $10 \mathrm{ng} / \mathrm{ml}$ of each of the constituent cytokines as is typically employed many in vitro studies of cytokine biology. For each experiment, four groups of three T75 flasks per group were incubated either with mixtures of Th1, Th2, M/M cytokines or additional medium (control) for 6 hours. Three sets of separate experiments consisting of control, Th1, M/M and Th2 stimulated cultures were performed.

\section{Cytotoxicity}

As reported $[15,16]$, we examined the cytokine-induced effect on cell death in mixed CNS glial cell cultures by incubating cultures from 6 hours to 4 days with the cytokine mixtures. Cell death was determined by uptake of $0.4 \%$ trypan blue [38].

\section{RNA extraction}

Cultures were washed and frozen after 6 hours of incubation with cytokine mixtures or additional medium. RNA was extracted employing TRIzol (Gibco BRL, Grand Island, NY) followed by Qiagen RNeasy kits (Qiagen, Valencia, CA). The RNA was quantitated at $\mathrm{A}_{260 \mathrm{~nm}}$ and the quality was assessed by at $A_{260} \mathrm{~nm} / A_{280 \mathrm{~nm}}$. The $28 \mathrm{~S} / 18 \mathrm{~S}$ ratio was assessed using a Bioanalyzer 2100 (Agilent Technologies, Wilmington, DE), and was $>1.7$ for all samples.

\section{Expression analysis}

Biotin-labeled RNA fragments were prepared and hybridized to the Affymetrix rat RG-U34A microarray at $45^{\circ} \mathrm{C}$ for 16 hours, as previously described $[15,16]$. Subsequent signal amplification was performed employing biotinylated anti-streptavidin antibody. The RG-U34A chip contains 7,985 genes. The control and three cytokine-incubated cultures from one experiment were analyzed with one gene chip for each sample and three separate experiments using different cultures were analyzed.

\section{Data analysis}

Data were analyzed by comparing the average of the replicates from each of the separate 3 sets of experiments. Affymetrix data were analyzed with dChip v1.2 to correct for background and calculate gene expression values [39]. We analyzed values from 3 separate experiments employing the t-test in GeneSpring comparing Th1, M/M and Th2 with control. Multiple testing analyses that compare all 7,985 genes at different levels of stringency using the Bonferoni and false discovery value (FDV) are statistically most rigorous, but at such high levels of stringency, there were very few changes that reached statistical significance. In order to increase sensitivity and allow identification of potentially important biologic changes, we employed a lower level of stringency $[15,16]$. In these screening studies at a single time point, we have arbitrarily chosen to represent as probably significant those genes in which the mean expression was $>2$ fold (upregulation) or $<-2$ fold 
(downregulation) compared to expression in controls ( $\mathrm{p}$ $<0.2)$ [15]. We believe this is reasonable given that our experiments consisted of biological replicates that are prone to greater variability than experimental replicates. A similar $\mathrm{p}$ value was used in a gene array analysis of MS lesions [2]. The recent literature suggests that a 2-fold cutoff using the Affymetrix platform produces a low false positive rate [40].

\section{Quantitative real time-polymerase chain reaction (QRT- $P C R$ ) expression analysis}

Expression of message for iNOS was analyzed by QRTPCR on an ABI 7500 Fast System, using ABI Taqman rat specific gene expression assays. RNA was extracted as above and reversed transcribed. Relative expression levels were calculated with GAPDH as the internal reference, using the delta-delta $\mathrm{Ct}$ method [41]. The values from the treated cultures were compared to those from control. Those ratios were averaged for the three experiments, then expressed as fold changes in the treated cultures relative to control for comparison with the gene array results. Each PCR value represents the average from 2-3 separate experiments.

\section{Results \\ Mixed CNS glial cell cultures}

As in our earlier papers, cultures consisted of approximately 35\% each of oligodendrocytes and astrocytes and $10 \%$ microglia. The remaining cells were glial cell precursors including A2B5 positive oligodendrocyte precursors. Endothelial cells and neurons were not present. Viability was $>98 \%$ in all cultures control and cytokine stimulated, at all time points examined ( 6 hours to 4 days) demonstrating the lack of cytotoxicity under these conditions.

\section{Overview of cytokine effects on early gene expression}

In the preceding papers we first described changes in CNS glia in genes for proteins predominantly associated with the immune system including major histocompatibility molecules, several adhesion and extracellular matrix molecules, cytokines and chemokines and their receptors and complement components [15]. Because of our interests in the effects of cytokines on the production of factors important in oligodendrocyte, axonal and neuronal function, in a second paper we compared the effects of the different cytokine mixtures on expression of genes for neurotrophins, growth factors, related receptors and structural proteins [16]. This third paper summarizes our findings for cytokine-induced changes in glial expression of genes for proteins associated with metabolism, signaling and regulation as well as neurotransmitters and ion channels. As noted, this is a series of screening experiments and therefore Tables 1 and 2 were prepared using the criteria of $>2$ fold (increased expression) or $<-2$ fold (decreased expression) with a $\mathrm{p}$ value of $<0.2$ for one or two repli- cates of the gene transcript $[15,16]$. Unknown genes (ESTs) are not presented.

\section{Neurotransmitters and receptors}

All three cytokine mixtures had regulatory effects on message levels for a wide range of message levels for neurotransmitters and their receptors as well as on transporters involved with transmitters including glutamate, adrenergic, cholinergic, glycine, serotonergic, dopaminergic and purinergic systems (Table 1 ). The only adrenergic receptor affected was alpha $2 \mathrm{c}-4$, upregulated 2.5 fold $(\mathrm{p}<0.05)$ by Th1 cytokines. Among cholinergic receptors, the largest change was for nicotinic cholinergic receptor alpha5, downregulated -2.3 fold $(\mathrm{p}<0.05)$ by Th1. Dopaminergic receptors $\mathrm{A} 3$ and $\mathrm{D} 1$ were markedly downregulated -8 to 14 fold by Th 1 and Th 2 cytokines. Among several changes in glutamate receptors, Th1 upregulated ionotropic glutamate receptor delta 1 by 2.7 fold ( $<<0.01$ ), but markedly downregulated metabotropic glutamate receptor $7 \mathrm{~b}$ by 9.5 fold $(\mathrm{p}<0.01)$. Neuropeptide $Y$ receptor 5 was downregulated by both Th1 and MM cytokine, -18 fold ( $\mathrm{p}<$ $0.10)$ and -8 fold $(p<0.20)$, respectively, while the substance P precursor preprotachykinin A was downregulated -7 fold $(\mathrm{p}<0.10)$ by Th2. For purinergic receptors, the most robust changes were -3 fold $(\mathrm{p}<0.05)$ downregulation of P2X1by Th2, and upregulation of P2Y2 by MM and Th2, 3.5 fold and 2.4 fold, respectively, both $\mathrm{p}<0.05$.

\section{Ion channels}

Th1, M/M and Th2 cytokines had primarily downregulatory effects on expression of a very large number of genes for proteins that are components of ion channels including $\mathrm{Na}, \mathrm{K}, \mathrm{Ca}$ and $\mathrm{Cl}$ channels, both voltage-gated and non-voltage gated (Table 1). For example, Th1 and Th2 downregulated the voltage-gated alpha $1 \mathrm{D} \mathrm{L}$ type $\mathrm{Ca}++$ channel by -4 and -7 fold respectively, both $\mathrm{p}<0.05$. A large number of $\mathrm{K}+$ channels were downregulated by $\mathrm{Th} 2$ cytokines, with fewer downregulated by Th1 or MM cytokines. The voltage-gated 1 alpha sodium channel was robustly downregulated by Th1 and MM cytokines, -9 fold $(\mathrm{p}<0.05)$ and -7 fold $(\mathrm{p}<0.10)$ respectively, while Th2 cytokines uniquely downregulated the 1 beta isoform, 2.5 fold, $\mathrm{p}<0.01$.

\section{ATPase ion exchangers}

In addition to the effects on ion channels shown in Table 1 , there were effects on several ATPase ion exchangers. With the exception of upregulation of Ca++ATPase (plasma membrane 1 ) by $\mathrm{M} / \mathrm{M}$ cytokines, several ATPase ion exchangers were downregulated by each of the cytokine mixtures (Table 1).

\section{Apoptosis}

The cytokine mixtures induced up and down regulation of several genes for proteins involved in control of apoptosis 
Table I: Changes in early gene expression: neurotransmitters, ion channels and exchangers, apoptosis, mitochondria and glutathione metabolism

\begin{tabular}{|c|c|c|c|c|}
\hline \multicolumn{2}{|c|}{ NEUROTRANSMITTERS AND RECEPTORS } & \multirow[t]{2}{*}{ ThI } & \multirow{2}{*}{$\begin{array}{l}\mathbf{M} / \mathbf{M} \\
2.07^{*}\end{array}$} & \multirow[t]{2}{*}{ Th2 } \\
\hline S50879 & acetylcholinesterase $\mathrm{T}$ subunit & & & \\
\hline AF050662 & activity and neurotransmitter-induced early gene 10 & & $-3.89 *$ & $-5.27 * *$ \\
\hline AF050664 & activity and neurotransmitter-induced early gene 12 & & $2.79 *$ & \\
\hline AF05066I & activity and neurotransmitter-induced early gene 9 & $-2.91 *$ & $-4.64 * *$ & $-3.7 I^{*}$ \\
\hline$\times 57659$ & adrenergic receptor, alpha 2 c-4 & $2.53^{* * *}$ & & \\
\hline MI6406 & cholinergic receptor, muscarinic $\mathrm{ml}$ & & $-2.05^{*}$ & $-2.07 *$ \\
\hline J05231 & cholinergic receptor, nicotinic, alpha 5 & & $-2.29 * * *$ & \\
\hline L08227 & cholinergic receptor, nicotinic, alpha 6 & $-3.26^{*}$ & & \\
\hline L31619 & cholinergic receptor, nicotinic, alpha 7 & & $-2.14 * *$ & $-2.29 * *$ \\
\hline L31622 & cholinergic receptor, nicotinic, beta 2 & & $-2.33^{* *}$ & \\
\hline M35077 & dopaminergic receptor $\mathrm{Al}$ & $-12.11 * * *$ & & $-14.19 * * *$ \\
\hline Al7753 & dopaminergic receptor D3 & $-10.31 * * *$ & $-5.21 *$ & $-8.28 * *$ \\
\hline L08493 & GABA-A receptor, alpha 4 & & $-2.0^{*}$ & \\
\hline S56679 & glutamate receptor, AMPA-selective A & & & $-3.31 * * *$ \\
\hline U08255 & glutamate receptor, ionotropic, delta I & $2.68 * * * * *$ & & \\
\hline AF02733I & glutamate receptor, ionotropic, kainate 5 & & $2.15^{*}$ & \\
\hline$D \mid 3211$ & glutamate receptor, ionotropic, NMDA 2A & & $-3.02 * *$ & $-3.50 * * *$ \\
\hline X96790 & glutamate receptor, metabotropic 7b. & $-9.46 * * * *$ & $-3.02 * *$ & $-3.50 * * *$ \\
\hline DI68I7 & glutamate receptor. metabotropic 7 & & $-2.19 *$ & \\
\hline U28504 & glutamate transporter, vesicular, family 17 & $-3.29 *$ & & \\
\hline$\times 55246$ & glycine receptor, alpha I & & & $-3.05^{* * * *}$ \\
\hline D00833 & glycine receptor, alpha I subunit & $-2.21 *$ & $-7.08 * * * *$ & \\
\hline X5728I & glycine receptor, alpha 2 subunit & $-2.36 * * *$ & & \\
\hline LI 3600 & glycine transporter I & $2.86 * * *$ & & $2.12^{* * *}$ \\
\hline U66274 & neuropeptide $Y$ receptor 5 & $-18.76 * *$ & $-8.72 *$ & \\
\hline$\times 56306$ & preprotachykinin A (substance P precursor) & & & $-7.17^{* *}$ \\
\hline L46874 & proton-driven peptide transporter. & $-2.10 * *$ & $-3.50 * * *$ & \\
\hline
\end{tabular}


Table I: Changes in early gene expression: neurotransmitters, ion channels and exchangers, apoptosis, mitochondria and glutathione metabolism (Continued)

\begin{tabular}{|c|c|c|c|c|}
\hline X9056I & purinergic receplor P2X, ligand-gated 3 & & & $-5.56^{*}$ \\
\hline X80477 & purinergic receptor $\mathrm{P} 2 \mathrm{X}$, ligand-gated I & $-3.23 *$ & & $-3.0 * * *$ \\
\hline AF020758 & purinergic receptor $\mathrm{P} 2 \mathrm{X}$, ligand-gated 2 & & $-3.86^{*}$ & $-3.8 I^{*}$ \\
\hline X95882 & purinergic receptor $\mathrm{P} 2 \mathrm{X}$, ligand-gated 7 & & $-2.10 *$ & \\
\hline U56839 & purinergic receptor P2Y, G-protein coupled 2 & & $3.51 * * *$ & $2.4 I^{* * * *}$ \\
\hline Y31।433 & purinergic receptor P2Y, G-protein coupled 4 & & & $-2.53^{*}$ \\
\hline X66842 & serotonergic receptor $2 \mathrm{~B}$ & $-2.09 * * *$ & & \\
\hline U20907 & serotonergic receptor 4 & & & $-6.05 * * *$ \\
\hline
\end{tabular}

\section{ION CHANNELS}

\begin{tabular}{|c|c|c|c|c|}
\hline M99222 & $\mathrm{Ca}++$ channel, A/P type, alpha I, splice variant & $-3.75^{*}$ & & \\
\hline M57682 & $\mathrm{Ca}++$ channel, voltage-gated, $\mathrm{L}$ type, alpha ID & $-4.62 * * *$ & $-3.39 *$ & $-7.36^{* * * *}$ \\
\hline D26III & $\mathrm{Cl}$ - channel ( $\mathrm{ClC}-\mathrm{K} 2 \mathrm{~L}$ and $\mathrm{ClC}-\mathrm{K} 2 \mathrm{~S})$, splice variant & $-3.13^{*}$ & $-2.02 *$ & \\
\hline X62894 & Cl- channel, voltage-gated, I (skeletal muscle) & & $-2.80 * *$ & $-2.59 *$ \\
\hline$X 78461$ & K+ inwardly-rectifying channel, JI2 (kir 3.3/IRK3) & & $2.05^{*}$ & \\
\hline U69884 & $\mathrm{K}+$ channel, small conductance $\mathrm{Ca}++$-activated & $-3.17^{*}$ & & $-2.55^{*}$ \\
\hline L3577। & $\mathrm{K}+$ channel, inwardly-rectifying, $\mathrm{J} 5$ & & & $-3.56 * * * *$ \\
\hline L77929 & $\mathrm{K}+$ channel, inwardly-rectifying, J9 & & & $-2.49 *$ \\
\hline U40603 & $\mathrm{K}+$ channel, large conductance $\mathrm{Ca}++$ activated $\mathrm{M}$ alphal & $-3.50^{*}$ & & $-3.61 *$ \\
\hline AB0I0963 & $\mathrm{K}+$ channel, large conductance $\mathrm{Ca}++$-activated $\mathrm{M}$ beta $\mathrm{I}$ & & & $-2.20 * * *$ \\
\hline DI0709 & K+ channel, IskI (epithelial), EI & & & $2.50^{* * * *}$ \\
\hline AF03।384 & $\mathrm{K}+$ channel, voltage-gated, $\mathrm{K} 3$ & & $-2.45^{*}$ & $-2.36 * *$ \\
\hline AF087453 & $\mathrm{K}+$ channel, voltage-gated, KQT-like 2 & & $-3.39 *$ & \\
\hline AF087454 & $\mathrm{K}+$ channel, voltage-gated, Q3 & & $-2.56^{*}$ & $-2.18^{*}$ \\
\hline Y17606 & $\mathrm{K}+$ channel, voltage-gated, SI & $-4.17 * *$ & $-3.80 *$ & $-4.68^{*}$ \\
\hline J04731 & $\mathrm{K}+$ channel, voltage-gated, shaker related 2 & $-7.17^{*}$ & & \\
\hline$X 16003$ & K+ channel, voltage-gated, shaker related 2 . & & $-2.44^{*}$ & \\
\hline U72410 & $\mathrm{K}+$ inwardly-rectifying channel, J3 (GIRKI) & & & $2.75^{* * *}$ \\
\hline M22253 & $\mathrm{Na}+$ channel, voltage-gated, I alpha & $-9.23 * * *$ & $-6.92 * *$ & \\
\hline M91808 & $\mathrm{Na}+$ channel, voltage-gated, I beta & & & $-2.46 * * * *$ \\
\hline
\end{tabular}


Table I: Changes in early gene expression: neurotransmitters, ion channels and exchangers, apoptosis, mitochondria and glutathione metabolism (Continued)

\begin{tabular}{|c|c|c|c|c|}
\hline AF000368 & $\mathrm{Na}+$ channel, voltage-gated, 9 alpha & $-3.36^{*}$ & & \\
\hline AA89I75I & $\mathrm{Na}+$ channel, voltage-gated, 3 alpha (CIN3) & & & $-2.10 * *$ \\
\hline Y00766 & $\mathrm{Na}+$ channel, voltage-gated. 3 alpha (CIN3) & & & $-2.76 * *$ \\
\hline \multicolumn{5}{|c|}{ ATPase ION EXCHANGERS } \\
\hline M99223 & $\mathrm{Ca}++$ ATPase, cardiac, fast twitch I & $-3.80 * *$ & $-2.82 *$ & $-2.70 * *$ \\
\hline AA800212 & $\mathrm{Ca}++$ ATPase, cardiac, slow twitch 2 & $-2.06 *$ & & $-2.35^{*}$ \\
\hline All 72499 & $\mathrm{Ca}++$ ATPase, plasma membrane I & & $3.0 * * *$ & \\
\hline X76452 & $\mathrm{Ca}++$ ATPase, plasma membrane 4 & & & $-2.06 * * *$ \\
\hline AA956437 & ER ATPase, peroxisome biogenesis factor I & $-2.35^{*}$ & & \\
\hline U949II & $\mathrm{H}+/ \mathrm{K}+\mathrm{ATPase}$, nongastric, alpha $2 \mathrm{a}$ & & $-2.30 * * *$ & \\
\hline M90398 & $\mathrm{H}+/ \mathrm{K}+\mathrm{ATPase}$, nongastric, alpha $2 \mathrm{a}$ & & $-2.73 *$ & \\
\hline UI5I76 & $\mathrm{Na}+/ \mathrm{K}+\mathrm{ATPase}$, alpha 4 & $-3.15^{*}$ & & $-2.86^{*}$ \\
\hline \multicolumn{5}{|c|}{ APOPTOSIS } \\
\hline $\mathrm{H} 31839$ & $\mathrm{Bcl} X$ & $2.35^{* *}$ & & \\
\hline AF02567I & caspase 2 & & $-2.93 * * * *$ & $-2.63 * * * *$ \\
\hline AF072I 24 & caspase 7 & $3.71 * * *$ & $3.17^{* *}$ & \\
\hline M33605 & cytolysin & $-2.06 * * *$ & & $-2.22 * * *$ \\
\hline $\mathrm{A} 1639313$ & huntingtin associated protein interactive protein & $-2.40 * * *$ & $-2.34^{*}$ & \\
\hline All 76462 & programmed cell death 2 & & $-2.47^{* * * *}$ & \\
\hline
\end{tabular}

\section{MITOCHONDRIA}

\begin{tabular}{|c|c|c|c|c|}
\hline AJ007488 & I6s ribosomal RNA, mitochondrial & $-4.1 * * * *$ & & $-2.8 I^{* *}$ \\
\hline$X 72758$ & COX Vla2, Complex IV & $-3.16 *$ & & \\
\hline M20I83 & COX VlcI, Complex IV & $-3.76 * *$ & & \\
\hline MIOI40 & creatine kinase (muscle) & & $-2.02 *$ & $-2.01 *$ \\
\hline Al044488 & ferredoxin I & $-2.27 *$ & & $-2.61^{*}$ \\
\hline D26393 & hexokinase II & $2.75^{*}$ & & \\
\hline X87884 & mitochondrial capsule selenoprotein. & & & $-2.88^{*}$ \\
\hline AA799479 & NADH dehydrogenase (ubiquinone), Complex I & & $-2.43^{* * *}$ & \\
\hline AA89165I & NADH dehydrogenase (ubiquinone), Complex I & $-2.20^{*}$ & $-2.6 I^{* * *}$ & \\
\hline
\end{tabular}


Table I: Changes in early gene expression: neurotransmitters, ion channels and exchangers, apoptosis, mitochondria and glutathione metabolism (Continued)

\begin{tabular}{|c|c|c|c|c|}
\hline Al75973 & NADH dehydrogenase (ubiquinone), Complex I & & & $-2.61^{*}$ \\
\hline X59736 & sarcomeric mitochondrial creatine kinase. & & $-5.18^{*}$ & \\
\hline Y00497 & superoxide dismutase 2 & $3.79 * * *$ & $5.82 * * * * *$ & $2.00 * *$ \\
\hline X6804I & superoxide dismutase 3 & $-2.96 * *$ & & \\
\hline X59793 & ubiquitous mitochondrial creatine kinase & & $-2.61 * *$ & \\
\hline A04674 & uncoupling protein I, proton carrier & $-2.19 * * *$ & & \\
\hline \multicolumn{5}{|c|}{ GLUTATHIONE-RELATED } \\
\hline U73।74 & glutathione reductase & $2.07^{*}$ & $2.74 * *$ & \\
\hline AlI 38143 & glutathione S-transferase, theta 2 & $-2.04 * *$ & & \\
\hline S72506 & glutathione S-transferase, Yc2 subunit & & $-5.0 * *$ & $-3.01 *$ \\
\hline $\mathrm{Al} 235747$ & glutathione-S-transferase, alpha (Ya) & & $-2.36^{*}$ & $-2.22 * * *$ \\
\hline M8I855 & P-glycoprotein, multi-drug resistance I & $5.45^{* *}$ & $5.10^{* * *}$ & \\
\hline
\end{tabular}

Values represent averages of fold changes from three separate experiments for each cytokine mixture compared to control. The accession numbers are from Genbank.

***** $<$ <0.01; **** $<0.05$; ** $p<0.10$; ${ }^{*} \mathrm{p}<0.20$.

Table 2: Changes in early gene expression: gene regulation, signaling, cytoplasmic transport and metabolism

\begin{tabular}{|c|c|c|c|c|}
\hline \multicolumn{5}{|c|}{ TRANSCRIPTION FACTORS } \\
\hline U04860 & aryl hydrocarbon receptor & $-2.48 * * * * *$ & $-2.66 * *$ & \\
\hline$\times 14788$ & CREB & $2.46 *$ & & $2.02 *$ \\
\hline $\mathrm{Hil} 677$ & elF5 (elongation initiation factor 5 ) & & $2.47^{* *}$ & \\
\hline $\mathrm{Al03194}$ & elF5 (elongation initiation factor 5 ) & & $2,06 * * *$ & \\
\hline Al638955 & fox-I homolog & $4.83 * *$ & & $4.08 * * * *$ \\
\hline LI326I & hepatic nuclear factor 3 (forkhead homolog I) & & $2.09 * * *$ & \\
\hline L09647 & hepatic nuclear factor 3 beta & $-2.23 * *$ & $-2.29 *$ & $-2.35 * *$ \\
\hline $\mathrm{ABOI} 774$ & hepatic nuclear factor 3 gamma & & & $-2.21^{*}$ \\
\hline$\times 57 \mid 33$ & hepatic nuclear factor 4 alpha & $-2.61 * *$ & $-4.80 * * * *$ & $-3.46 * * * *$ \\
\hline$\times 57133$ & hepatic nuclear factor 4 alpha & $-6.63 * * *$ & $-3.69 * * *$ & $-2.92 * *$ \\
\hline DI0554 & hepatic nuclear factor 4 alpha & & & $-2.38 * *$ \\
\hline AA89104I & junB & $4.49 * * *$ & & $2.48 * *$ \\
\hline
\end{tabular}


Table 2: Changes in early gene expression: gene regulation, signaling, cytoplasmic transport and metabolism (Continued)

\begin{tabular}{llr}
\hline X54686 junB & $2.29^{* * * * *}$ & $2.13^{* * * * *}$ \\
\hline L26267 & NFkappa B, pl05 subunit & $3.97^{* * * *}$ \\
\hline L23862 & POU domain & $-2.47^{* * *}$
\end{tabular}

\section{NUCLEAR RECEPTORS}

\begin{tabular}{|c|c|c|c|c|}
\hline U40064 & PPAR delta & $2.31 * *$ & $2.06 * *$ & \\
\hline$A B 011365$ & PPAR gamma & $-5.4 I^{* * * * *}$ & $-4.52 * * * *$ & $-2.09 *$ \\
\hline \multicolumn{5}{|c|}{ SIGNALING } \\
\hline L26986 & adenylyl cyclase, type 8 & & $-4.11^{*}$ & \\
\hline U73503 & calmodulin kinase II, gamma E & $-2.26^{*}$ & & \\
\hline U09583 & fyn-related kinase (src homology) & & & \\
\hline AB007688 & homer & $4.03 *$ & $4.03 * * * * *$ & \\
\hline AA900503 & jagged I & $2.15^{*}$ & $2.35^{*}$ & \\
\hline L38483 & jagged I & & $2.38^{* * * *}$ & \\
\hline UI3396 & Janus kinase 2 (JAK 2) & $5.20 * * *$ & $4.97^{* * *}$ & \\
\hline UI3396 & Janus kinase 2 (JAK 2) & $2.34 * * *$ & & \\
\hline AJ000557 & Janus kinase 2 (JAK 2) & & $3.36 * * *$ & \\
\hline LI495। & lyn protein non-receptor kinase & $2.45^{* *}$ & $2.00 *$ & \\
\hline LI 4782 & lyn protein non-receptor kinase & $2.17^{* * * *}$ & & \\
\hline AA946094 & lyn protein non-receptor kinase & $2.14 * *$ & & \\
\hline X96488 & MAP kinase 12 & $-2.07^{*}$ & & \\
\hline M95437 & phosphodiesterase IB & & $-2.36 * *$ & \\
\hline AL235758 & protein kinase $A, 2$, regulatory subunit & & $-2.15^{*}$ & \\
\hline MI8330 & protein kinase $\mathrm{C}$, delta & $2.11 * *$ & & \\
\hline U69109 & protein tyrosine kinase $2 \mathrm{~B}$ & $4.59 * *$ & $3.17^{* *}$ & \\
\hline AF063890 & protein tyrosine kinase $2 \mathrm{~B}$ & $3.30 * * *$ & & \\
\hline All I 3289 & protein tyrosine phosphatase, non-receptor & $2.31 * * *$ & $2.45^{* * *}$ & \\
\hline AF05398 & ras GTPase activating protein & $-2.04 * *$ & & \\
\hline U69702 & receptor serine threonine kinase & $-2.50 *$ & $-2.56^{*}$ & \\
\hline U69702 & receptor serine threonine kinase & & $-2.56^{*}$ & \\
\hline
\end{tabular}


Table 2: Changes in early gene expression: gene regulation, signaling, cytoplasmic transport and metabolism (Continued)

\begin{tabular}{|c|c|c|c|c|}
\hline AF097887 & Rho family GTPase & & $-2.07^{* * * *}$ & \\
\hline AA892553 & STAT I & $10.30 * * *$ & & \\
\hline$\times 91810$ & STAT 3 & $2.49 * * * *$ & $2.42 * * * *$ & \\
\hline U24I75 & STAT 5a & $3.13^{* * *}$ & $4.4 I^{* * *}$ & \\
\hline L27III2 & stress activated protein kinase alpha II & & & $2.85^{* * *}$ \\
\hline \multicolumn{5}{|c|}{ CYTOPLASMIC TRANSPORT AND DEGRADATION OF PROTEINS } \\
\hline AF077354 & heat shock $70 \mathrm{kDa}$ protein 4 & & $2.24 * *$ & \\
\hline AA799492 & proteasome (prosome, macropain) alpha 6 & $9.69 * * * *$ & & \\
\hline AA891383 & proteasome (prosome, macropain) alpha 6 & $3.29 * * *$ & & \\
\hline D45249 & proteasome activating subunit alpha & $2.12^{* * *}$ & & \\
\hline D45250 & proteasome activating subunit beta & $3.68 * * *$ & & \\
\hline D21799 & proteasome subunit RC7-I & $2.12^{* * *}$ & & \\
\hline DI0757 & proteasome subunit R-RING & $6.76 * * * *$ & & \\
\hline DI0757 & proteasome subunit R-RING & $6.45^{* *}$ & & \\
\hline AJ22444I & proteasome subunit R-RING & $-3.62 * *$ & $-3.78 * * * *$ & \\
\hline $\mathrm{H} 31236$ & similar to ubiquitin-conjugating enzyme E2D 2 & & & $-2.50 *$ \\
\hline S73007 & synuclein alpha (SYN I) & $2.87 * *$ & & \\
\hline S73008 & synuclein beta (SYN 2) & $-3.82 * *$ & $2.58^{* * *}$ & \\
\hline AA874859 & ubiquitin ligase (NEDD 4) & $-2.25^{*}$ & $-3.19 * * *$ & \\
\hline L38482 & ubiquitin-conjugating enzyme & & $2.01 * *$ & \\
\hline U56407 & ubiquitin-conjugating enzyme E2D 2 & $-4.18 * * *$ & $-6.38 * * *$ & $-4.76 * * *$ \\
\hline AA685I 52 & ubiquitin-like protein (NEDD 6) & $2.7 I^{* * * *}$ & $2.90 * * *$ & \\
\hline
\end{tabular}

\section{LIPID SYNTHESIS}

\begin{tabular}{|c|c|c|c|c|}
\hline S78687 & 3-OH-3-methylglutaryl CoA reductase & $-2.34 * *$ & $-2.34 * *$ & \\
\hline j02749 & acetyl CoA acyl transferase & & $-2.34 *$ & $-2.29 *$ \\
\hline j03808 & acetyl CoA carboxylase & $-2.40 *$ & & \\
\hline ABOI0428 & cytosolic acyl CoA thioesterase I & $3.91 *$ & & \\
\hline M9559I & farnesyl phosphate farnesyl transferase & & $-2.11 * * *$ & \\
\hline Al004900 & fatty acid CoA ligase, long chain 2 & $2.47 * * * *$ & & \\
\hline
\end{tabular}


Table 2: Changes in early gene expression: gene regulation, signaling, cytoplasmic transport and metabolism (Continued)

\begin{tabular}{|c|c|c|c|c|}
\hline AA925424 & fatty acid CoA ligase, long chain 4 & $-4.83^{* * *}$ & $-4.27^{* * * * *}$ & \\
\hline M33648 & mitochondrial 3-OH-3-methylglutaryl CoA synthase & & & $-2.72 * *$ \\
\hline Y09333 & mitochondrial acyl CoA thioesterase & $2.68 * *$ & & \\
\hline D005I2 & mitochondrial fatty acid acetyl CoA thiolase & $-2.39 *$ & & \\
\hline AA800303 & phospholipid scramblase & $3.16 *$ & & \\
\hline U07683 & UDP-galactose ceramide galactosyl transferase & $-3.14^{*}$ & & \\
\hline AF047707 & UDP-glucose:ceramide glycosyltransferase & $2.57 * * *$ & $2.61 * * *$ & \\
\hline \multicolumn{5}{|c|}{ LIPID SIGNALING } \\
\hline AB00999 & CDP-diacylglycerol synthase & $9.91 * * * *$ & $6.45 * * * *$ & \\
\hline AB00999 & CDP-diacylglycerol synthase & $2.52 * * *$ & & $6.40 * * * *$ \\
\hline AA818983 & diacylglycerol kinase beta & $-4.21 * *$ & & \\
\hline U10303 & EDG, endothelial sphingolipid GPCR & & $-6.17 * * * *$ & $-2.65^{*}$ \\
\hline AA85998I & myo-inositol monophosphatase & & $-2.01 * * *$ & \\
\hline D88666 & phosphatidyl serine specific phospholipase A & & $3.08 * *$ & \\
\hline D00036 & phospholipase A2, group IB & & $-4.15^{*}$ & \\
\hline U03763 & phospholipase A2, group 5 & & $-4.17 * *$ & \\
\hline LI4322 & phospholipase C beta I & $-2.37 * *$ & & \\
\hline
\end{tabular}

\section{STEROID AND VITAMIN D RELATED}

\begin{tabular}{|c|c|c|c|c|}
\hline U89280 & I7-beta hydroxy sterol reductase & $-2.81 * *$ & & $-3.53 * * * *$ \\
\hline X97754 & I7-beta hydroxy sterol reductase, type I & $-4.53 * * *$ & & \\
\hline L04619 & 25-OH vitamin D3 24-hydroxylase (Cyp24al) & & $-5.20 *$ & $-4.42^{*}$ \\
\hline M95058 & steroid 5-alpha reductase 2 & $-2.04 * *$ & & \\
\hline MI3646 & testosterone 6-beta hydroxylase & & $-6.91 * * *$ & $-2.03^{*}$ \\
\hline Y07534 & vitamin D3 25-hydroxylase (Cyp27al) & $2.49 *$ & & \\
\hline \multicolumn{5}{|c|}{ MISCELLANEOUS } \\
\hline X0236I & alpha-fetoprotein & $-2.50 *$ & $-2.56^{*}$ & $-2.49^{*}$ \\
\hline AA998229 & alpha-fetoprotein & & & $-2.22 * *$ \\
\hline M90065 & angiotensin receptor, type Ib & & & $-5.02 * * * *$ \\
\hline U01908 & angiotensin receptor, type 2 & $-3.82 * *$ & & \\
\hline
\end{tabular}


Table 2: Changes in early gene expression: gene regulation, signaling, cytoplasmic transport and metabolism (Continued)

\begin{tabular}{|c|c|c|c|c|}
\hline J02720 & arginase I & & & $4.82^{* * * *}$ \\
\hline$\times 03369$ & beta tubulin $2 b$ & $-4.09 *$ & $-4.90 *$ & $-11.96 * * *$ \\
\hline U60758 & carbonic anhydrase II & $2.46 *$ & & $2.10^{*}$ \\
\hline Al043968 & caveolin 3 & & $-2.44^{*}$ & \\
\hline AA8I 7854 & ceruloplasmin & & $2.56^{*}$ & \\
\hline L33869 & ceruloplasmin & & $2.04 *$ & \\
\hline U49049 & chapsyn-IIO & $-4.05^{*}$ & $-4.77 * *$ & $-29.4^{* * * * *}$ \\
\hline U09538 & fyn-related kinase (src homology) & & $-2.49 * *$ & \\
\hline J03624 & galanin & $5.03 * *$ & $3.22^{* * *}$ & \\
\hline S57565 & histamine $\mathrm{H} 2$ receptor & $-2.62 * *$ & & $-2.17 * *$ \\
\hline MII566 & kallikrein S3 & $-2.34 * *$ & $-2.48 * *$ & \\
\hline$M 27217$ & kallikrein-related (rGK-8) & & $-2.88 * *$ & \\
\hline$A B 005900$ & low density lipoprotein receptor I & $4.06 * *$ & $2.18^{* *}$ & $5.84 * *$ \\
\hline Al0753I & low density lipoprotein receptor I & $3.19 * * * *$ & & $5.40 * * *$ \\
\hline Al030685 & nestin & $-2.77^{*}$ & & \\
\hline U03699 & nitric oxide synthase 2 (iNOS) & $14.69 * * *$ & $|4.6| * * *$ & \\
\hline AA892953 & similar to carbonic anhydrase & & $2.19 *$ & \\
\hline U0936I & VIP receptor 2 & $-3.14^{*}$ & & \\
\hline
\end{tabular}

Values represent averages of fold changes from three separate experiments for each cytokine mixture compared to control. The accession numbers are from Genbank.

$* * * * \mathrm{p}<0.01$; *** $\mathrm{p}<0.05 ;{ }^{* *} \mathrm{p}<0.10$; $*_{\mathrm{p}}<0.20$.

(Table 1) including caspase 2, downregulated -3 fold, $\mathrm{p}<$ 0.05 by both $\mathrm{MM}$ and Th2 cytokines, and caspase 7, downregulated -3 fold by Th 1 and MM cytokines.

\section{Mitochondria and related proteins}

There were cytokine mixture-induced changes in expression in genes of some mitochondrial proteins which are listed in Table 1, including a 4-6 fold ( $\mathrm{p}<0.05)$ upregulation of super oxide dismutase 2 (SOD2) by Th1 and $\mathrm{MM}$, and an apparent -4 fold $(\mathrm{p}<0.01)$ decrease for $16 \mathrm{~S}$ mitochondrial ribosomal RNA.

\section{Glutathione-related}

The genes for several proteins involved in glutathione metabolism and secretion were regulated by the different types of mixtures of cytokines (Table 1). Subunits of glu- tathione S-transferase were generally downregulated, while both Th1 and MM upregulated P-glycoprotein(multi-drug resistance protein) by 5 fold, $\mathrm{p}<0.10$ and $\mathrm{p}<0.05$, respectively.

\section{Transcription factors}

Th1 cytokines markedly upregulated junB, CREB and the p105 subunit of NF $\kappa B$. Both Th1 and M/M cytokines altered expression of genes for several other transcription factors, while the Th2 cytokines had minimal effects (Table 2). All three cytokines markedly upregulated message levels of junB $(2-3$ fold, $\mathrm{p}<0.01)$ and downregulated hepatic nuclear factor alpha ( -3 to -7 fold, $\mathrm{p}<0.05$.). Both Th1 and M/M cytokines upregulated the expression of the gene for NF kappa B p105 subunit and downregulated the aryl hydrocarbon receptor (Table 2). 
Table 3: QRT-PCR validation of gene array results for cytokineinduced changes in gene expression at 6 hours

\begin{tabular}{lccc}
\hline Gene & Cytokine & Array & PCR \\
\hline iNOS & & & \\
& ThI & 14.7 & $35.9+/-18.8$ \\
& M/M & 14.6 & $371+/-146$ \\
& Th2 & NC & $-3.7+/-0.9$ \\
arginase & & & \\
& ThI & NC & $1.05+/-0.28$ \\
& M/M & NC & $5.37+/-2.03$ \\
& Th2 & 4.82 & $20.9+/-5.16$ \\
P glycoprotein & & & \\
& & & \\
& ThI & 5.4 & $2.51+/-2.54$ \\
& M/M & 5.1 & $3.77+/-1.84$ \\
& Th2 & $N C$ & $1.99+/-0.28$ \\
\hline
\end{tabular}

RNA extracts from 2 experiments for iNOS and 3 experiments for arginase and $\mathrm{P}$ glycoprotein were analyzed by QRT-PCR, as described in Methods. Values are averages +/- range. In agreement with the gene array results, ThI and $M / M$ cytokines markedly upregulated expression of iNOS in the mixed glial cultures; Th2 cytokines upregulated arginase; and ThI and M/M cytokines upregulated $P$ glycoprotein. Differences from the gene array were a decrease in iNOS by Th2, an increase in arginase by $M / M$ and an increase in $P$ glycoprotein by Th2 cytokines.

Values for iNOS, +/- range; values for arginase and P glycoprotein, +/S.D.

\section{Nuclear receptors}

Th1 and M/M cytokines upregulated the gene for peroxisome proliferator activator receptor $\delta$ (PPAR $\delta$ ) by 2 fold $(\mathrm{p}<0.10)$, and downregulated the gene for PPAR $\gamma$ by -5 fold ( $\mathrm{p}<0.01)$. Th2 cytokines downregulated the gene for PPAR $\gamma$ but had no effect on PPAR $\delta$ (Table 2).

\section{Signaling}

The cytokine mixtures had effects on the expression of genes for many signal transduction molecules, some of which are presented in Table 2. Among these are STAT1, 3 and 5, JAK2, homer and protein kinase 2 B. Of interest, only one gene in this category was affected by Th2 cytokines, stress activated protein kinase alpha 2, upregulated 3 fold $(\mathrm{p}<0.05)$.

\section{Cytoplasmic transport and degradation of proteins}

Th1, M/M and Th2 cytokines had effects on the genes for several proteins involved in synthesis, degradation and intracellular transport of proteins including synucleins, proteasome subunits, ubiquitin conjugating enzymes and heat shock protein (HSP) $70 \mathrm{kDa}$ (Table 2). For example, proteasome (macropain) alpha 6 was upregulated 10 fold ( $\mathrm{p}<-.01$ ) by Th1 cytokines, while the ubiquitin-conjugating enzyme E2D 2 was downregulated -4 to -6 fold $(\mathrm{p}<$ $0.05)$ by all three cytokine mixtures.

\section{Lipid synthesis and signaling}

As noted in Table 2, the genes for several proteins involved in lipid metabolism and signaling were regulated by the different cytokine mixtures. For example, fatty acid CoA ligase long chain 4 was downregulated -4 to -5 fold ( $\mathrm{p}<0.05$ fold) by Th1 and Mm cytokines, while UDP-glucose ceramide glycosyl transferase was upregulated 3 fold $(\mathrm{p}<0.05)$. With regard to lipid signaling, CDP diacylglycerol synthase was markedly upregulated 6-10 fold $(\mathrm{p}<0.01)$ by all three cytokines, while EDG (endothelial sphingolipid GPCR) was downregulated -6 fold ( $\mathrm{p}<0.01$ ) by MM cytokines.

\section{Steroid and vitamin $D$ related}

Specific genes regulating proteins involved in sterol and vitamin $\mathrm{D}$ metabolism were also regulated by the cytokine mixtures (Table 2). Thus, 17-beta hydroxyl sterol reductase was downregulated -4 to -5 fold $(\mathrm{p}<0.05)$ by Th1 and Th2 cytokines, and testosterone 6-beta hydroxylase was downregulated -7 fold $(\mathrm{p}<0.05)$ by MM cytokines.

\section{Miscellaneous proteins}

There were a large number of genes for proteins not included in the above categories that are potentially of importance in understanding the pathogenesis of MS, as well as protective and reparative mechanisms. These are listed in Table 2. Of note, Th1 and MM cytokines upegulated nitric oxide synthase 2 (iNOS) by 15 fold ( $p<0.05$ ), while Th2 cytokines markedly downregulated genes for angiotensin receptor type $1 \mathrm{~b}(-5$ fold), beta tubulin $2 \mathrm{~b}$ (12 fold), and chapsyn-110 (-29 fold), all $\mathrm{p}<0.05$, but upregulated arginase and low density lipoprotein receptor 1 by 5 fold $(\mathrm{p}<0.05)$.

\section{QRT-PCR}

We validated expression changes in three genes by QRTPCR: iNOS, the enzyme that synthesizes NO from arginine; arginase, the enzyme that breaks down arginine, thus limiting production of $\mathrm{NO}$; and P-glycoprotein (multi-drug resistance 1), an $\mathrm{ABC}$ transporter involved in regulation of glutathione levels. As noted in Table 3, we were able to confirm striking upregulation of the gene for iNOS by Th1 and $\mathrm{M} / \mathrm{M}$ at 6 hours employing QRT-PCR. Although no effect on the gene for iNOS expression was observed at 6 hours in response to Th2 cytokines on microarray, we detected modest downregulation employing QRT-PCR. For arginase, we confirmed upregulation by Th2, with no change induced by Th1; however, in contrast to the array results, PCR indicated some upregulation of arginase by MM at 6 hours, rather than no change. For $\mathrm{P}$ glycoprotein, PCR showed upregulation by Th1 (in two of three analyses) and $\mathrm{MM}$, as on the gene array, but also indicated a modest increase with Th2 rather than no change. The results for these three genes show relatively 
good agreement, and indicate that the arrays are not giving false positive results, but in some instances may give false negative results, suggesting that PCR may be more sensitive than the gene array.

\section{Discussion}

In our two preceding papers, we showed marked differential early effects of Th1 cytokines, M/M cytokines and Th2 cytokines on glial expression of a variety of genes, including those for immune-related molecules [15] and for neurotrophins, growth factors and structural proteins [16]. In addition, following the 6 hours of cytokine exposure used in these studies, we saw changes in expression of a large number of genes involved in signaling, regulation and metabolism. Some of these changes might be predicted from known effects of cytokines in vitro and in EAE or MS tissue, while other changes were unexpected. In contrast to the in vivo studies, our examination of an early 6 hour time point provides information about what might be some of the initial responses of glia per se to these cytokines.

\section{Neurotransmitters and receptors}

Glial cells have been reported to express different neurotransmitters and receptors as well as transporters for these transmitters [23,42-45]. With increasing evidence that both oligodendrocyte and neuronal/axonal damage may be caused by glutamate induced toxicity [46-50], and that other glutamate receptors may be protective [51], the effects of cytokine mixtures on different GluR may influence and modify the effects of glutamate. AMPA, kainate and NMDA receptors may be important in oligodendrocyte toxicity in MS and EAE [52-57] whereas upregulation of metabotropic GluRs (mGluRs) may provide protection [58]. The effects of upregulation of AMPA, NMDA and kainate GluR on neuronal death are well recognized [59]. It is of interest that Th1 and M/M upregulated GluRs associated with cell toxicity whereas all three cytokine mixtures markedly downregulated metabotropic mGluR7b. The group III mGluRs, including mGluR7, inhibit production of RANTES induced in astroglia by TNF- $\alpha$ or IFN- $\gamma$ [60]. We previously reported upregulation of the gene for RANTES by Th1 and M/M cytokines [15].

The role of other transmitters in glial cell function is not as well understood. In addition to receptors for well established neurotransmitters and classically described ion channels $(\mathrm{Ca}++, \mathrm{K}+$ and $\mathrm{Na}+)$, we detected effects on genes for the purinergic $\mathrm{P} 2 \mathrm{X}$ receptors, some of which serve as ligand gated ion channels [61], and the P2Y receptors which act as $\mathrm{G}$ protein coupled receptors when ligated by extracellularly released nucleotides, as occurs in inflammation and other stressful conditions within the CNS. The purinergic receptors modify the response of astrocytes to cytokines such as IL- $1 \beta$ and TNF- $\alpha$ and mod- ify astrocyte functions including $\mathrm{Ca}++$ influx [62-64], as well as modulating transport of other ions [65]. The P2X7 receptor is found in resting and activated microglia in epileptic brain and several other neurologic diseases [66], and plays a role in microglial proliferation [61] and migration [23]. The P2X7 receptor is expressed in reactive astrocytes and microglia/macrophages in MS lesions [62], and is transiently upregulated by the $\mathrm{M} / \mathrm{M}$ cytokine IL-1 $\beta$ in cultured fetal human astrocytes, resulting in increased iNOS activity [64]. We noted modest downregulation of the gene for the P2X7 receptor with $M / M$ at 6 hours in our mixed glial cultures, suggesting that the mixture of cytokines or the presence of other glial cell types may modulate the glial responses to IL- $1 \beta$, or that upregulation seen in vivo and in vitro in other studies may be a secondary response occurring at later time points.

The different cytokine mixtures had variable effects on a large number of receptors for several other transmitters including dopaminergic, serotonergic, cholinergic, adrenergic and melanocortin as well as the previously discussed purinergic receptors. The downregulation of the genes for the D1 and D3 dopamine receptors by the cytokine mixtures was especially striking. All three types of glia are known to express dopamine receptors, and D3 dopamine receptors may play roles in oligodendroglial differentiation and myelination [67], as well as protection of oligodendrocytes against glutamate oxidative stress and oxygen glucose deprivation [68]. Binding of neurotransmitters to their receptors on microglial cells seem to be important in microglial function [23].

It is also of interest that several of the neuronal nicotinic acetylcholine receptors are involved in downregulation of proinflammatory immune reactions in the systemic immune system, in particular the nicotinic $\alpha 7$ receptor $[69,70]$, which we found downregulated by both $\mathrm{M} / \mathrm{M}$ and Th2 cytokine mixtures. Further, attenuation of cholinergic signaling with the acetylcholinesterase inhibitor physostigmine results in inhibition of CNS inflammation and development of EAE [71]. Conversely, we found that $\mathrm{M} / \mathrm{M}$ cytokines upregulated the gene for the acetylcholinesterase $\mathrm{T}$ subunit, which could lead to increased acetylcholinesterase and a decreased "protective" cholinergic response.

Expression of genes for several transporters for glutamate and glycine were also observed along with changes in the genes for the $\mathrm{R} 5$ receptor for neuropeptide $\mathrm{Y}$ receptor 5 and preprotachykinin A (precursor of substance $\mathrm{P}$ ). The role of such receptors and transporters in glial cells is not clear. Of interest, changes were found in activity of neurotransmitter-induced early genes 9, 10 and 12 . It is not known if these cytokine mixtures have a similar effect on the same genes and their proteins in various subpopula- 
tions of neurons. If they do, this would have major implications on neuronal and axonal dysfunction in MS and other diseases characterized by CNS inflammation and/or microglial activation [72], as well as symptoms in patients with MS such as depression, memory loss, abnormalities in other cognitive functions, fatigue and pain.

\section{Ion channels}

We observed cytokine induced changes in gene expression for many ion channels including $\mathrm{Na}+, \mathrm{K}+$ and $\mathrm{Ca}++$ channels. It is well established that glial cells have a wide variety of ion channels which are important in glial cell function [21,73-77] and that expression of some of these have been reported to be affected by cytokines in glial cells and neurons, as well as other types of cells [21,78-81]. Cytokine effects on ion channels and ion exchangers clearly are important in axonal and neuronal function and viability as well as likely contributing to symptomatology in patients with MS [82-86]. Changes in genes for ion channels have been reported in the CNS in MS and EAE $[2,87]$.

There have been reports of inflammatory mediators such as inducible nitric oxide synthase (iNOS) inducing upregulation of certain $\mathrm{Na}$ channels in neurons [84,88]. We observed significant effects on gene expression for a wide variety of ion channels in glial cells at 6 hours of incubation suggesting a direct effect of cytokines on expression of genes for some or all of these channels in glia. Changes in the distribution of ion channels could contribute to glial cell dysfunction. If similar changes were induced directly in neurons/axons, these changes could contribute to plasticity as well as to axonal and neuronal cell death. While such changes in neuronal ion channels and failure and reversal of ion exchangers, particularly $\mathrm{Ca}++$ exchangers $[89,90]$, could result from failure of mitochondrial energy metabolism $[10,91]$, our results also raise the possibility of axonal dysfunction and ultimately death by direct effect of cytokines on expression of genes for ion channels and ATPase ion exchangers (see below). The cytokine mixtures also likely regulate ion channels on inflammatory cells such as lymphocytes, and ion channels are known to affect lymphocyte function [92].

\section{ATPase ion exchangers}

Th1 downregulated the genes for $\mathrm{Na}+\mathrm{K}+$ ATPase, $\alpha 4$ polypeptide and $\mathrm{Ca}++$ transporting ATPase. M/M upregulated the genes for $\mathrm{Ca}++$ transporting ATPase and $\mathrm{Ca}++$ ATPase, plasma membrane 1. Th2 likewise downregulated the genes for several ATPase ion transporters including $\mathrm{Na}^{+} / \mathrm{K}^{+}$ATPase $\alpha 4$ polypeptide, $\mathrm{Ca}++$ transporting ATPase, $\mathrm{Ca++-pumping} \mathrm{ATPase} \mathrm{isoform} \mathrm{4,} \mathrm{H}+/ \mathrm{K}+$-ATPase $\alpha 2$ gene, alternatively spliced and $\mathrm{H}^{+} / \mathrm{K}^{+}$ATPase, nongastric, $\alpha$ polypeptide, nongastric; and the $\mathrm{Na}^{+} / \mathrm{H}^{+}$ion exchanger (Table 1).

\section{Apoptosis}

The possible role of oligodendrocyte cell death through apoptosis via caspases [93] or via other pathways to cell death [94] in MS lesions continues to be controversial, and it is likely that apoptosis as a mediator of oligodendrocyte death varies in different lesions [95]. Neuronal cell death by what appears to be apoptosis is also seen [96]. Up and downregulation of expression of various genes for proteins involved in apoptosis including caspases and $\mathrm{Bcl} \mathrm{X}$ were noted. Th1 and M/M cytokines both induced upregulation of the genes for caspase $7, \mathrm{a}$ downstream effector caspase involved in caspase-dependent apoptosis [97], and $\mathrm{Bcl} \mathrm{X}$, a protein which inhibits apoptosis [98,99]. M/M cytokines downregulated the gene for caspase 2, a caspase implicated in oligodendrocyte cell death via the p75 receptor [93]. The gene for cytolysin (a constituent of lymphocyte toxic granules) was downregulated by both Th1 and Th2 cytokines, and Th2 and $\mathrm{M} / \mathrm{M}$ cytokine mixtures both downregulate the gene for the protein programmed cell death 2 .

Mutations in the gene for the protein huntingtin (Htt) result in Huntingon's chorea. Htt interacts with several proteins. One of these proteins is called htt-interacting protein (HIP-1). When HIP1 is bound to normal Htt, it inhibits apoptosis in certain neurons and Htt seems to be involved in endocytosis as well [100-103]. In addition abnormal huntingtin interferes with normal ubiquitinproteosome function and one could readily postulate that downregulation of proteins such as HIP-1 that interact with htt could also lead to abnormal protein aggregation such is seen in many degenerative diseases including Huntington's disease, where it is the htt that is qualitatively abnormal [104]. There was downregulation of the gene for HIP-1 by Th1 and M/M cytokines.

Changes in expression of mitochondrial protein genes, including genes associated with some apoptotic pathways, were noted (see below).

\section{Mitochondria and related proteins}

Changes in mitochondrial related genes have been noted in MS cortical gray matter in patients with long-standing chronic MS [10], and failure in mitochondrial associated energy metabolism may be important in axonal and neuronal degeneration and cell death [89,91]. Most of the detected changes were reduced expression of genes, particularly components of complex I, III and IV. Decreased expression of COX subunits I and IV (Complex IV) has been detected in oligodendroglia, astroglia and axons, but not in microglia, in acute Type III MS lesions [12]. In our CNS glial cultures, we found predominately downregulation of genes associated with mitochondria. Th1 cytokines upregulated genes for hexokinase II and superoxide dismutase 2 (Mn++ SOD2), and downregulated genes for 
NADH dehydrogenase (Complex I), COX VIa and COX VIc (Complex IV), ferredoxin 1, and perhaps for 16 s ribosomal RNA, which is a component of the large subunit of the mammalian mitochondrial ribosome, responsible for synthesis of 13 proteins localized in the inner mitochondrial membrane [105]. This latter finding has yet to be confirmed. M/M cytokines upregulated genes for SOD2 and down regulated the genes for NADH dehydrogenase and creatine kinases. Th2 cytokines down regulated genes for NADH dehydrogenase and $16 \mathrm{~S}$ ribosomal RNA. Th1 down regulated the gene for SOD3, an extracellular $\mathrm{Cu}^{++}$/ $\mathrm{Zn}^{++}$SOD. None of the cytokine mixtures had an effect on the gene for the mitochondrial protein $\mathrm{Cu}^{++} / \mathrm{Zn}^{++}$SOD1; some familial forms of amyotrophic lateral sclerosis (ALS) are associated with mutations in this gene [106]. One could postulate that inflammatory cytokines, perhaps products of activated microglia, at first stimulate transcription of genes for some mitochondrial enzymes, but decreased expression of the $16 \mathrm{~S}$ subunit of the mitochondrial ribosome could lead to ongoing downregulation of genes and their proteins critical for mitochondrial function in oligodendrocytes and neurons.

\section{Glutathione-related}

We observed effects on the genes for several proteins involved in glutathione metabolism and secretion. Glutathione serves a protective function by reducing the effect of free radicals produced via oxidative stress $[107,108]$, and the cytokine mixtures had significant effects on genes for several proteins involved in synthesis, regulation and release of glutathione. Th1 upregulated the gene for $\mathrm{P}$ glycoprotein/multidrug resistance protein 1/MDR1 (Pglycoprotein/ABCB1), as did M/M cytokines. MDR1, which in addition to inhibiting the therapeutic effects of drugs, has effects on vascular structures and influences secretion of glutathione by cells such as astrocytes [109111]. In addition to astrocytes, it has been detected in microglia, oligodendrocytes, endothelial cells and neurons $[112,113]$. Glutathione is more abundant in astrocytes than in other brain cell types, which may contribute to the relative resistance of astrocytes to ischemia and other pathologic processes that involve oxidative stress. Changes in glutathione may also contribute to the relative vulnerability of oligodendrocytes and precursors at different stages of maturation to oxidative stress [107,114-116]. Glutathione also modulates prostaglandin metabolism [117]. We describe cytokine modulation of expression of several genes associated with prostaglandin metabolism [15], and prostglandin D synthase has been reported to be upregulated in MS lesions [2].

\section{Transcription factors}

Some genes for transcription factors were upregulated, quite predictably, such as NF- $\kappa \mathrm{B}$ p105 in the presence of IL-1 or TNF- $\alpha$ (Th1 and M/M cytokines). Cyclic AMP response element binding protein 1 (CREB) was upregulated in response to Th1 cytokines.

The upregulation of the gene for CREB by Th1 cytokines may result from the effect of TNF- $\alpha[118]$, although $\mathrm{M} / \mathrm{M}$ cytokines which also contain this cytokine did not appear to have the same effect.

Jagged 1 is a transcription factor reported to be upregulated in astrocytes by TGF- $\beta$ and through Hes and notch 1 leads to inhibition of myelination [119], although its presence may not be necessary to inhibit myelination [120]. Given the report of upregulation of jagged 1 by TGF- $\beta$ in astrocytes [119], an unexpected finding in our experiments was upregulation of jagged 1 by Th1 and M/ $M$ cytokine mixtures which do not contain TGF- $\beta$ and the failure of the Th2 cytokine mixture, which contains this cytokine/growth factor, to upregulate jagged 1 . These differences could relate to differences in the target tissues (single cell types versus mixtures of different cell types), species and/or effects of a single cytokine versus mixtures of cytokines, effects of some of the induced proteins and their influence on downstream signaling. At 6 hours none of the cytokine mixtures had any discernable effect on expression of notch1 or Hes.

In addition we observed effects on gene expression of other transcription factors including hepatic nuclear factors (HNF), POU and elongation initiation factor 5 , important in initial stress responses.

\section{Nuclear receptors}

PPARs are nuclear receptors originally associated with lipid metabolism but subsequently found to also be involved in cellular differentiation. Th1 and M/M cytokines both upregulated the gene for PPAR $\delta$ and down regulated the gene for $\operatorname{PPAR} \gamma$, whereas Th2 cytokines down regulated the gene for $\operatorname{PPAR} \gamma$ and had no effect on the gene for PPAR $\delta$. TNF- $\alpha$, a component of both the Th1 and M/M cytokine mixtures, has been reported to down regulate the gene for PPAR $\delta$ [121]. This is another potential example of differences in the effects of single cytokines versus mixtures of cytokines. Ligation of PPAR $\gamma$ results in down regulation of inflammatory responses and can inhibit EAE [122,123] and has lead to studies to evaluate such agents, which are used in the treatment of diabetes and hyperlipidemia, as therapy for MS. Activation of PPAR $\delta$ with different ligands than those that react with PPAR $\gamma$ causes activation and accelerates differentiation of oligodendrocytes in vitro [124]. How the differential regulation of the PPARs affects inflammation and the potential for favorably influencing remyelination through these receptors is not as yet clear.

\section{Signaling}

Th1 and $\mathrm{M} / \mathrm{M}$ cytokines markedly upregulated Janus kinase 2 (JAK) as well as several members of the STAT 
family, in keeping with the well known activation of the JAK/STAT pathway by inflammatory cytokines. Studies in brain ischemia indicate that increased signaling via the JAK/STAT pathway occurs predominantly in microglia rather than astroglia or neurons [125]. We found a 10 fold increase in STAT 1 with Th1 cytokines, consistent with an increase in STAT 1 identified by gene array analysis in both chronic and active MS lesions [126].

The gene for homer, a key protein in Group I metabotropic GluR signaling, was upregulated by Th1 and Th2 cytokines [127-130]. In addition there were effects on expression for genes of protein kinase $\mathrm{C}$, protein kinase $\mathrm{A}$, protein tyrosine kinase 2B, CaM kinase II, Rho family GTPase, receptor serine threonine kinase, lyn protein nonreceptor kinase and fyn-related kinase. Fyn, the only src family kinase, is upregulated during oligodendrocyte differentiation [131] and signals through Rho family GTPases to regulate their morphologic maturation [132].

\section{Cytoplasmic transport and degradation of proteins}

Th1 cytokines upregulated the genes for $\alpha$ synuclein and for several proteasome proteins and ubiquitin-like protein (NEDD 6), and down regulated the genes for proteasome subunit R-RING (although as noted upegulated other transcripts of the R-RING subunit), $\beta$ synuclein (SYN 2), receptor serine threonine kinases, ubiquitin ligase (NEDD 4), and ubiquitin conjugating enzyme E2D 2. M/M cytokines upregulated the genes for NEDD 6 and SYN2, and downregulated the genes for ubiquitin-conjugating enzyme E2D 2, NEDD 4 and proteasome subunit R-RING. Th2 cytokines downregulated the genes for ubiquitin conjugating enzyme E2D 2 and similar to ubiquitinconjugating enzyme E2D 2. If changes in the expression of these genes result in changes in the level of these proteins, it would imply that inflammation could contribute to the changes in these proteins seen in sporadic forms of several degenerative disorders where synucleins and ubiquitin aggregation have been described $[133,134]$. The synucleins, considered neuronal proteins, are involved in synaptic function and have chaperone functions as well $[135,136]$. Th1 cytokines upregulated $\alpha$-synuclein, which has been detected transiently in rat oligodendrocytes in vitro [137] and in inclusions in glial cells in some CNS diseases including multisystem atrophy (MSA) [138]. Proteasomes are involved in transport of protein degradation products as well as in transport of MHC proteins and antigen within antigen presenting cells (APC).

Heat shock proteins (HSP) are upregulated in response to several types of cell stress stimuli [139]. One of several functions of HSP is acting as chaperones to help in normal transport of other proteins within the cytoplasm of many cell types. $\mathrm{M} / \mathrm{M}$ cytokines upregulated the gene for heat shock protein (HSP) $70 \mathrm{kDa}$. Interestingly upregulation of the gene for $\alpha / \beta$ crystalline which also serves as a stress response protein has been reported to be increased in MS lesions [2].

\section{Lipid synthesis}

Th1 cytokines altered gene expression for several enzymes involved in synthesis of fatty acids and phospholipids (Table 2). Both Th1 and $\mathrm{M} / \mathrm{M}$ cytokines downregulated message of the gene for HMGCoA reductase, the principal regulatory enzyme for cholesterol and other isoprenoids. Interestingly statins, which are inhibitors of this enzyme, are being tested as treatment for MS [139-142] because they inhibit experimental autoimmune encephalomyelitis (EAE), an animal model for MS. The mechanisms include decreased farnesylation causing a Th1 to Th2 shift and monocyte/macrophage inflammation [141,143-145], and perhaps alteration of other signaling pathways [16].

UDP-glucose:ceramide glycosyltransferase is upregulated in the presence of TNF- $\alpha$ (Th1 and M/M cytokines). This enzyme is involved in ceramide metabolism as part of both ceramide induced cell death via TNF-R type I signaling pathways, as well as catalyzing the initial step in ganglioside synthesis. Th1 cytokines also downregulated the gene for UDP-galactose ceramide galactosyltransferase (member 8 of the UDP-glucuronosyl transferase family). This enzyme is markedly upregulated during differentiation of oligodendroglia and synthesizes galactocerebroside, the major glycolipid of myelin and precursor to sulfatide. An early response to inflammatory cytokines has not been previously reported for the gene or the protein.

Notably Th1 cytokines upregulated the gene for phospholipid scramblase, which translocates phospholipids from one surface of the plasma membrane to the other.

In our initial paper we reported that Th1 and $M / M$ cytokines induced robust upregulation of genes for $A B C$ transporter 1, which among its several functions, translocates phosphatidyl choline and cholesterol to the outer membrane leaflet in astrocytes and neurons [146], and for $\mathrm{ABC}$ transporter 2, active in oligodendrocytes during myelination [147]. The ABC transporters are also important in intraceullar transport of other proteins including peptide epitopes with MHC class I molecules [15].

\section{Lipid signaling}

Th1 cytokines downregulated the gene for diacyl glycerol kinase beta, which phosphorylates diacyglycerol to produce phosphatidic acid, leading to termination of diacylglyceryol signaling via PKC, Ras GTPase and other signaling pathways.

IL-2, one of the components of the Th1 mixture, upregulates diacylglycerol kinase in myelin [148], raising the 
possibility that oligodendroglia are upregulating this gene in response to the Th 1 cytokines. In addition, the gene for CDP-diacylglycerol synthase, the enzyme that synthesizes phosphatidyl inositol from phosphatidic acid, is robustly upregulated by both Th1 and M/M cytokines, suggesting a switch from diacylglycerol to phosphatidyl inositol mediated signaling pathways. Conversely, the gene for myoinositol monophosphatase was downregulated by $\mathrm{M} / \mathrm{M}$ cytokines; this enzyme, the key enzyme inhibited by lithium, generates free inositol from inositol-3-phosphate derived from glucose-6-phosphate, and regulates levels of inositol available for synthesis of phosphatidyl inositol and its multi-phosphorylated derivatives critical for intracellular signaling and trafficking as well as calcium homeostasis. It is of note that lithium is currently being evaluated as a treatment of amyotrophic lateral sclerosis based on its effects on inositol pathways [149-152].

Sphingosine-1-phosphate plays a key role in cell survival and inflammatory responses [153]; the gene for one of its receptors, EDG (endothelial sphingolipid GPCR) was down regulated by both $\mathrm{M} / \mathrm{M}$ and Th2 cytokines. There has been a phase II trial in patients with MS of an oral agent called FTY72, which binds to the EDG (S1P) receptor (endothelial differentiation sphingolipid G-protein coupled receptor) [154]. A large Phase III study is underway. Inhibition of this receptor both blocks emigration from and favors homing of lymphocytes to secondary lymph structures, ostensibly without affecting T-cell viability or inhibiting memory T-cells. In experimental animals other inflammatory cells, such as monocytes and mature dendritic cells, are also affected and the protein is also found on endothelial cells. The drug has also been used in studies of treatment of other immune disorders [155-160] The S1P receptor EDG is also found in the CNS on glial cells [161-163]. The roles of S1P and its G-coupled receptor in the normal CNS are not known. It has recently been shown that activation of S1P results in changes in glial cells in vitro $[164,165]$. If FTY720 gains access to the CNS there is the potential to modulate the activity of S1P with uncertain consequences for the patient.

\section{Steroid and vitamin D related}

Several genes coding for enzymes involved in steroid metabolism were downregulated by each of the three cytokine mixtures, including the gene for testosterone 6beta-hydroxylase, markedly downregulated by $\mathrm{M} / \mathrm{M}$ cytokines. Of note, Th1 cytokines upregulated the gene for vitamin D3 25-hydroxylase, the enzyme catalyzing the first step in activation of dehydrocholesterol to the active hormone, 1, 25-hydroxy vitamin D3. However, both M/M and Th2 cytokines down regulated 25-OH vitamin D3 24hydroxylase, a key step in the inactivation of the active form of vitamin D3 [166]. Both are mitochondrial enzymes and members of cytochrome p450 family. In several studies vitamin D3 dietary supplementation prevented the onset and progression of EAE. In MBP-induced EAE in mice, the treated animals showed marked decreases in chemokines, iNOS and CD11b+recruitment into the CNS, perhaps due to activated $\mathrm{T}$ cell apoptosis [167]. One large study found that vitamin D3 supplementation reduced the risk of developing MS [168], while four smaller studies suggested a reduction in exacerbations (reviewed in Brown, 2006) [169]. Our findings suggest that both $\mathrm{M} / \mathrm{M}$ and Th2 cytokines might act to attenuate the effects of the active forms of vitamin D3.

\section{Miscellaneous proteins}

The classically proinflammatory Th 1 and $\mathrm{M} / \mathrm{M}$ cytokines markedly upregulated the gene for iNOS, a critical protein in generation of $\mathrm{NO}$, which gives rise to related reactive oxygen species such as peroxynitrite [170]. Increases in iNOS have been reported in the CNS in EAE and in MS [171-174]. There is evidence that NO could directly or indirectly, by forming peroxynitrite, damage oligodendrocytes, myelin and neurons/axons [175]. Reactive nitrogen species can also influence neuronal Na channels and thus cause damage, especially with rapid firing bare axons $[171,176]$. It has also been suggested that NO could have an immumodulatory effect on inflammatory cells. NO production in inflammatory cells and in glial cells is induced by iNOS. As described in Results, employing QRT-PCR we confirmed the upregulation of expression of the gene for iNOS by Th 1 and M/M cytokine mixtures and also found modest downregulation of the gene in response to Th2 cytokines (Table 3).

Galanin is a peptide in the CNS and PNS which is upregulated in response to injury $[177,178]$. While originally described in various neurons it has been demonstrated in glia as well.[179,180] and has a positive effect on neurite growth, cell survival and regeneration [181-183] as well as involved in interactions with hormones $[184,185]$, pain signaling pathways $[186,187]$ and other CNS functions $[188,189]$. Galanin receptors are also co-localized with cholinergic receptors in astroglia [190]. During oligodendrocyte differentiation, the gene for galanin is markedly downregulated [191]. Therefore upregulation by Th 1 and M/M cytokines may represent an early attempt of oligodendroglia to return to a less differentiated state, one capable of proliferation.

The alpha-fetoprotein that is increased in the serum of women in the last trimester of pregnancy has been shown to have immunosuppressive effects in EAE as well as in experimental autoimmune myasthenia gravis (EAMG) [192-195]. It also can suppress autoreactivity in vitro to two respective autoantigens, MBP and acetylcholine receptor (AChR). This has lead to the suggestion that it 
may be one of several factors responsible for inhibition of disease activity during the third trimester of pregnancy in patients with MS as well as MG. It is of some interest that expression of the gene for this potentially immunosuppressive protein is downregulated by Th1 and $\mathrm{M} / \mathrm{M}$ cytokines.

Nestin, an intermediate filament protein, is a marker of early neuronal cell development. It is also a marker of other progenitor cells, particularly glial cells in the CNS, and may be involved in cell proliferation [196-199]. The proinflammatory Th1 cytokine mixture down regulated the gene for nestin, which would be compatible with an inhibitory effect of such cytokines on neuronal and glial cell precursors.

VIPR2 binds VIP, a peptide shown to induce release of cytokines and other factors from glial cells [200,201]. Downregulation of this protein by Th1 cytokines secreted by infiltrating inflammatory cells or endogenous glia would inhibit the release of both cytokines and growth factors by glial cells.

We detected $\mathrm{M} / \mathrm{M}$ induced upregulation of a gene transcript for angiotensin receptor 2 (ATR2), whereas Th1 cytokines down regulated expression of the same transcript and Th2 cytokines down regulated a different ATR2 transcript. M/M cytokines upregulated the gene for ATR 1 . ATR 2 is expressed by endothelial cells as well as glial cells. ATR1 is also expressed by endothelial cells as well as other cells within the CNS. Angiotensin and ATR are involved with interactions with VEGF and other molecules and may be involved in CNS cell death via apoptosis [202204]. Increased expression of the gene for angiotensin, the ligand for angiotensin receptors, has been described in studies of MS brain tissue [205,206].

Two unexpected and novel findings were the marked decreases in expression of the genes for chapsyn-110 and beta tubulin by Th 2 cytokines. Chapsyn- 110 is a member of the PSD95/SAP90 protein family. The protein is found in postsynaptic densities in somatic/dendritic neuronal processes, and interacts with the C-terminus of subunits of the NMDA GluR and shaker-type potassium channel $[207,208]$. The protein is linked indirectly to microtubules and involved in clustering of the receptors and ion channels; its presence and function in glia have not been previously reported. The marked down regulation of chapsyn-110 along with that of beta tubulin in glia may lead to potentially neuroprotective disruption of signaling through NMDA receptors and potassium channels in these cells.

Ceruloplasmin is a metal binding protein which is increased in response to inflammatory signals. In the brain ceruloplasmin is important as a binder of iron, and in the absence of ceruloplasmin (aceruloplasminemia), iron is able to induce tissue injury by increasing lipid peroxidation [209-211]. M/M cytokines upregulated the expression of the gene for ceruloplasmin whereas Th 1 and Th2 cytokines had no effect. Effects on genes for iron binding proteins if resulting in sufficient increase in protein would down regulate free iron induced lipid peroxidation, whereas a reduction or even a failure of increase in such proteins could result in cell damage or even death.

Caveolins are a group of proteins that are important in the structure of cell membranes including neurons and myelin. They are components of the so called "lipid rafts", important constituents of plasma membranes. Caveolins 1,2 and 3 are upregulated in spinal cord of rat with EAE with caveolin 3 being expressed by astrocytes [212], although at 6 hours in vitro Th1 cytokines down regulated the expression of the gene for caveolin 3 .

Arginase 1 is involved in synthesis of polyamines which have been shown to improve axonal regeneration on myelin substrates [213]. Th2 upregulated the gene for this protein, which would favor axonal regeneration. Th2 cytokines, particularly IL-4, stimulate production of arginase by macrophages, and there is an inverse relationship between production of iNOS induced by Th1 cytokines and arginase induced by Th2 cytokines in these cells [214216]. By inhibiting production of nitric oxide, arginase may also play a neuroprotective role for motor neurons deprived of trophic factors [217]. Recently, loss of arginase 1 was shown to increase proliferation of neural stem cells [218]. One could postulate that the microglia may be the glial cells upregulating the gene for arginase in our system.

\section{Overview}

In this paper and the preceding two $[15,16]$, we have identified responses to cytokines that would be predicted from analysis of MS tissue, others identified following treatment of individual glial types in culture, and yet others that have not been previously reported. Among the genes predicted from analysis of MS plaques are those related to hypoxic/ischemic responses, inflammatory responses and neuroprotective responses. Most strikingly, our finding that transcription of these genes in glia is changed within 6 hours of exposure to the cytokines implicates the glia as primary responders in the amplification or suppression of damage in white matter. In this paper, we report early changes in a wide variety of genes related to neurotransmitter signaling and ion homeostasis in glial cells. The most striking changes were the decreases induced by Th 1 cytokines in dopaminergic receptors, metabotropic glutamate receptor $7 \mathrm{~b}$, and a receptor for neuropeptide Y. Identification of which glial type is responding and whether 
Table 4: Summary of most upregulated and downregulated gene expression

\begin{tabular}{|c|c|}
\hline MOST UPREGULATED & MOST DOWNREGULATED \\
\hline ThI & ThI \\
\hline nitric oxide synthase 2 (iNOS) & neuropeptide $Y$ receptor 5 \\
\hline STAT I & dopaminergic receptor $\mathrm{Al}$ \\
\hline CDP-diacylglycerol synthase & dopaminergic receptor D3 \\
\hline proteasome (prosome, macropain) alpha 6 & glutamate receptor, metabotropic $7 \mathrm{~b}$. \\
\hline proteasome subunit R-RING & $\mathrm{Na}+$ channel, voltage-gated, I alpha \\
\hline P-glycoprotein, multi-drug resistance I & $\mathrm{K}+$ channel, voltage-gated, shaker related 2 \\
\hline Janus kinase 2 (JAK 2) & hepatic nuclear factor 4 alpha \\
\hline fox-I homolog & PPAR gamma \\
\hline protein tyrosine kinase $2 \mathrm{~B}$ & fatty acid CoA ligase, long chain 4 \\
\hline caspase 7 & 17-beta hydroxy sterol reductase, type I \\
\hline cytosolic acyl CoA thioesterase I & diacyl glycerol kinase beta \\
\hline superoxide dismutase 2 & ubiquitin-conjugating enzyme E2D 2 \\
\hline$M / M$ & $M / M$ \\
\hline nitric oxide synthase 2 (iNOS) & neuropeptide $Y$ receptor 5 \\
\hline CDP-diacylglycerol synthase & glycine receptor, alpha I subunit \\
\hline superoxide dismutase 2 & $\mathrm{Na}+$ channel, voltage-gated, I alpha \\
\hline STAT $5 \mathrm{a}$ & testosterone 6-beta hydroxylase \\
\hline P glycoprotein (multi-drug resistance) & ubiquitin-conjugating enzyme E2D 2 \\
\hline Janus kinase 2 (JAK 2) & EDG, endothelial sphingolipid GPCR \\
\hline homer & dopaminergic receptor D3 \\
\hline NF kappa B, pI05 subunit & glutathione S-transferase, Yc2 subunit \\
\hline purinergic $P 2 Y$ receptor 2 & beta tubulin $2 b$ \\
\hline caspase 7 & hepatic nuclear factor alpha \\
\hline protein tyrosine kinase $2 b$ & chapsyn-I I0 \\
\hline $\mathrm{Ca}++$ ATPase, plasma membrane I & PPAR gamma \\
\hline Th2 & Th2 \\
\hline CDP-diacylglycerol synthase & chapsyn-II0 \\
\hline low density lipoprotein receptor I & dopaminergic receptor $\mathrm{Al}$ \\
\hline arginase I & beta tubulin $2 b$ \\
\hline fox-I homolog & dopaminergic receptor $\mathrm{D} 3$ \\
\hline stress activated protein kinase alpha II & $\mathrm{Ca}^{++}$channel, voltage-gated, $\mathrm{L}$ type alpha ID \\
\hline $\mathrm{K}+$ inwardly-rectifying channel, J3 (GIRKI) & preprotachykinin A (substance $\mathrm{P}$ precursor) \\
\hline jun $B$ & serotonergic receptor 4 \\
\hline purinergic $\mathrm{P} 2 \mathrm{Y}$ receptor 2 & purinergic receptor $\mathrm{P} 2 \mathrm{X}$, ligand-gated 3 \\
\hline glycine transporter I & angiotensin receptor, type Ib \\
\hline carbonic anhydrase II & ubiquitin-conjugating enzyme E2D 2 \\
\hline CREB & $\mathrm{K}+$ channel, voltage-gated SI \\
\hline superoxide dismutase 2 & 25-OH vitamin D3 24-hydroxylase \\
\hline
\end{tabular}

these changes result in long-lasting changes in gene expression, function, and interaction with neurons promise to be informative. With regard to changes in mitochondrial enzymes, the pattern of changes with Th1 cytokines was quite distinct from that seen with $\mathrm{M} / \mathrm{M}$ cytokines, while Th2 cytokines induced only a few more modest changes. With Th1 cytokines, marked downregulation of the COX VI subunit was seen; this differs from the decrease in the COX IV subunit reported in MS tissue, and may provide a clue to the very earliest changes occurring in mitochondrial function in glia exposed to proinflammatory cytokines, as may the very early downregulation of the 16s mitochondrial ribosomal RNA, which would effect all of the 13 mitochondrial encoded genes. Upregu- lation by Th1 of genes for transcription factors such as junB, NF- $\kappa \mathrm{B}$ and CREB might be predicted, while the decreases in HNF3 and 4 and the increase in the genes for the fox- 1 homolog and jagged 1 by Th1 cytokines in glia have not been previously reported. Again, the many changes seen in expression of genes for proteasome, ubiquitin and synuclein proteins with Th1 cytokines might be anticipated, but stand in contrast to the relatively few changes seen in response to $\mathrm{M} / \mathrm{M}$ and Th2 cytokines. Finally, lipid synthesis and signaling pathways have not been extensively explored in glia in response to cytokines; most notably, decreases by Th1 at 6 hours in the genes coding for synthesis of galactocerebroside implicate changes in oligodenroglial function, since the lipid serves 
as the precursor for sulfatide, shown to be critical for maintaining normal architecture and function at the nodes. The decrease in the gene for diacyl glycerol kinase and increase in CDP-diglyceride synthase suggests an early switch in signaling pathways within glia.

Table 4 summarizes the largest changes seen with each of the three cytokine mixtures, with the 12 most upregulated genes arranged in order from highest to lowest, and the 12 downregulated genes from most downregulated to least downregulated. While the magnitude of change in gene expression does not necessarily reflect the extent of biological relevance, the summary illustrates a number of changes in common between Th1 and M/M cytokines, as predicted by their predominance of proinflammatory cytokines. Very few genes were upregulated by Th2 cytokines in the categories analyzed in this study, only the 12 genes shown in the table.

\section{Vascular/Ischemia/Hypoxia}

It has been reported that certain MS lesions have features characteristic of ischemic or hypoxic injury to oligodendrocytes $[12,219]$ although inflammatory cells, particularly macrophages, are present in the lesions. Studies of normal appearing white matter in MS, employing gene array technology, have also shown changes in patterns of gene regulation consistent with ischemia and the response to ischemia [9]. It has also been suggested that local angiogenesis occurs in EAE and in MS [220]. We have identified early effects of these cytokine mixtures on molecules that are important in vascular pathology and angiogenesis as well as upregulated in ischemia and hypoxia. Obviously this includes a vast number of genes and gene products involved in transcription, cell signaling, mitochondrial function and apoptosis along with many others.

In addition to the changes in genes for proteins associated with apoptosis and mitochondria, in our current and prior studies $[15,16]$, we found that Th1 cytokines upregulated other genes reported to be regulated in the CNS in ischemia including adhesion molecules (ICAM-1, VCAM), cytokines and chemokines and their receptors (IL-1 $\beta$, MCP-1), death and survival proteins (Bcl-X), proteases and inhibitors (MMP-9) and growth factors (FGF 1 and NGFRp75). Th1 cytokines did not affect the gene for e-selectin but upregulated the gene for its ligand. Among other genes for proteins regulated in CNS ischemia, Th1 cytokines down regulated genes for neurotrophins and their receptors (BDNF, NT3 and trkB), and cytokines, chemokines and their relevant receptors (several related to TGF- $\beta$ ). M/M cytokines upregulated genes for cell adhesion molecules (ICAM-1, VCAM), HSP 70, cytokines, chemokines and receptors (IL-1 $\beta$, IL-1R type 1 , IL-6, MCP1), FGF 5 and 10, and MMPs and inhibitors (MMP9,
TIMP-1) and downregulated genes of interest for response to ischemia, including TGF- $\beta 3$, NT3, and FGF2. Th2 cytokines upregulated ischemia related genes for growth factors (BDNF, FGF 10 and 14, FGF-R1), cytokines and chemokines and receptors (IL-6, IL-1R type I and TGF$\beta R 2$ ) and down regulated genes for IL-1R type I, and NT3. Differential expression of many of these genes were reported in the NAWM of some patients with MS [9].

As previously reported $[15,16]$, Th1, M/M and Th2 cytokines had varying effects on the genes for molecules that are involved in altering in the cells of the blood brain barrier including several adhesion molecules and MMPs although our cultures do not contain endothelial cells. Some of these molecules are undoubtedly important in glial cells as well. In a previous study, we detected upregulation of the gene for VEGF [16]. Upregulation of VEGF could contribute to endothelial cell proliferation seen in some MS lesions producing local hypoxia and oligodendroglial death. The function of VEGF in glial cells as well as other non-glial non-neuronal cells, such as pericytes, which conceivably might be in our cultures is not known. Since inflammatory cytokines were able to upregulate the gene for VEGF as well as other genes that are associated with ischemia and the response to ischemia, our data suggests that cytokine release secondary to inflammation can lead to changes compatible with hypoxia and perhaps to induction of hypoxia itself.

We recognize the limitations of microarray analysis as well as gene expression studies since post-transcriptional and post-translational changes are not detected. In addition proteins such as receptors may be present in sufficient amount to be ligated and involved in a biologic process without requiring additional protein in the short run and thus no upregulation of gene for that protein. Nevertheless as a screening technique to obtain an overview of proteins that may be important in a particular process as well as the complexities of the effect of a mixture of factors on a mixture of cells, we believe that this is a promising approach. In addition microarray technology allows discovery of unexpected findings in complex experiments. Such findings may turn out to be both interesting and important.

\section{Competing interests}

RPL has served as a consultant to Teva Neuroscience as well as on the speakers' bureau for Teva Neuroscience. He has also served as a consultant to Genentech, Biogen/Idec, EMD Serono and MediciNova. He has had research funding from Teva Neuroscience, Biogen/Idec, EMD Serono, Bayer Health, Glaxo Smith Kline, BioMS, Abbott, Novartis and Accorda. The other authors declare that they have no competing interests. None of the authors hold stocks or shares in any pharmaceutical company or hold or are 
applying for any patents relating to the contents of the manuscript.

\section{Authors' contributions}

RPL and JAB were involved in the conception, design, acquisition of data, analysis and interpretation of data, and the drafting of the manuscript. BB and $\mathrm{LN}$ performed the tissue culture experiments and $\mathrm{BB}$ performed the indirect immunofluorescence experiments. The QRT-PCR was done by DS and for some of the arginase analyses by ER. The gene array procedures were carried out under the supervision of SL and the biometric analysis was carried out by BY. All authors read and approved the final version.

\section{Acknowledgements}

This study was funded by Teva Neuroscience, the Parker Webber Chair in Neurology Endowment and the Mary Parker Neuroscience Fund of the Detroit Medical Center/Wayne State University School of Medicine.

We wish to thank Joshua Adler, Steven Douglas, Paula Dore-Duffy, James Garbern, Alexander Gow, John Kamholz, Jeffrey Loeb, Kenneth Maiese, and Raymond Mattingly for helpful discussions.

\section{References}

I. Whitney LW, Becker KG, Tresser NJ, Caballero-Ramos Cl, Munson PJ, Prabhu VV, Trent JM, McFarland HF, Biddison WE: Analysis of gene expression in multiple sclerosis lesions using cDNA microarrays. Ann Neurol 1999, 46:425-428.

2. Lock C, Hermans G, Pedotti R, Brendolan A, Schadt E, Garren H, Langer-Gould A, Strober S, Cannella B, Allard J, et al.: Gene-microarray analysis of multiple sclerosis lesions yields new targets validated in autoimmune encephalomyelitis. Nat Med 2002, 8:500-508

3. Tajouri L, Mellick AS, Ashton KJ, Tannenberg AE, Nagra RM, Tourtellotte WW, Griffiths LR: Quantitative and qualitative changes in gene expression patterns characterize the activity of plaques in multiple sclerosis. Brain Res Mol Brain Res 2003, I 1 9: I70-183.

4. Mycko MP, Papoian R, Boschert U, Raine CS, Selmaj KW: cDNA microarray analysis in multiple sclerosis lesions: detection of genes associated with disease activity. Brain 2003, 126: 1048-1057.

5. Mycko MP, Papoian R, Boschert U, Raine CS, Selmaj KW: Microarray gene expression profiling of chronic active and inactive lesions in multiple sclerosis. Clin Neurol Neurosurg 2004, 106:223-229.

6. Lindberg RL, De Groot CJ, Certa U, Ravid R, Hoffmann F, Kappos L, Leppert D: Multiple sclerosis as a generalized CNS disease comparative microarray analysis of normal appearing white matter and lesions in secondary progressive MS. J Neuroimmunol 2004, 152:154-167.

7. Allen IV, McQuaid S, Mirakhur M, Nevin G: Pathological abnormalities in the normal-appearing white matter in multiple sclerosis. Neurol Sci 200I, 22:141-144.

8. Allen IV, McKeown SR: A histological, histochemical and biochemical study of the macroscopically normal white matter in multiple sclerosis. J Neurol Sci 1979, 41:81-91.

9. Graumann U, Reynolds R, Steck AJ, Schaeren-Wiemers N: Molecular changes in normal appearing white matter in multiple sclerosis are characteristic of neuroprotective me chanisms against hypoxic insult. Brain Pathol 2003, 13:554-573.

10. Dutta R, McDonough J, Yin X, Peterson J, Chang A, Torres T, Gudz T, Macklin WB, Lewis DA, Fox RJ, et al.: Mitochondrial dysfunction as a cause of axonal degeneration in multiple sclerosis patients. Ann Neurol 2006, 57:478-489.

II. Dutta R, McDonough J, Chang A, Swamy L, Siu A, Kidd GJ, Rudick R, Mirnics K, Trapp BD: Activation of the ciliary neurotrophic factor (CNTF) signalling pathway in cortical neurons of multiple sclerosis patients. Brain 2007, 130:2566-2576.
12. Mahad D, Ziabreva I, Lassmann H, Turnbull D: Mitochondrial defects in acute multiple sclerosis lesions. Brain 2008, 131:1722-1735.

13. Lisak R, Studzinski D, Bealmear B, Nedelkoska L, Benjamins J: Kinetics of gene expression in central nervous system glial cells induced by Th1, Th2 and monocyte/macrophage cytokines. Mult Scler 2005, I I(Suppl 2):SI36-SI37.

14. Lisak R, Studzinski D, Bealmear B, Nedelkoska L, Benjamins J: Regulation of genes for neurotrophins and their receptors in central nervous system mixed glial cell cultures by mixtures of cytokines. Mult Scler 2007, 13:S219.

15. Lisak R, Benjamins J, Bealmear B, Yao B, Land S, Skundric DS: Differential effects of ThI, monocyte/macrophage and Th2 cytokine mixtures on early gene expression for mmunerelated molecules by central nervous system mixed glial cell cultures. Mult Scler 2006, 12:149-168.

16. Lisak RP, Benjamins JA, Bealmear B, Nedelkoska L, Yao B, Land S, Studzinski D: Differential effects of ThI, monocyte/macrophage and Th2 cytokine mixtures on early gene expression for glial and neural-related molecules in central nervous system mixed glial cell cultures: neurotrophins, growth factors and structural proteins. J Neuroinflammation 2007, 4:30.

17. Nicot A, Ratnakar PV, Ron Y, Chen CC, Elkabes S: Regulation of gene expression in experimental autoimmune encephalomyelitis indicates early neuronal dysfunction. Brain 2003, | 26:398-4|2.

18. Gallo V, Patneau DK, Mayer ML, Vaccarino FM: Excitatory amino acid receptors in glial progenitor cells: molecular and functional properties. Glia 1994, I I:94- I0I.

19. Gallo V, Zhou JM, McBain CJ, Wright P, Knutson PL, Armstrong RC: Oligodendrocyte progenitor cell proliferation and lineage progression are regulated by glutamate receptor-mediated K+ channel block. J Neurosci 1996, 16:2659-2670.

20. Gallo V, Ghiani CA: Glutamate receptors in glia: new cells, new inputs and new functions. Trends Pharmacol Sci 2000, 21:252-258.

21 . Soliven B: Calcium signalling in cells of oligodendroglial lineage. Microsc Res Tech 200I, 52:672-679.

22. Kim WT, Rioult MG, Cornell-Bell AH: Glutamate-induced calcium signaling in astrocytes. Glia 1994, I I:173-184.

23. Pocock JM, Kettenmann $H$ : Neurotransmitter receptors on microglia. Trends Neurosci 2007, 30:527-535.

24. Fields RD, Stevens B: ATP: an extracellular signaling molecule between neurons and glia. Trends Neurosci 2000, 23:625-633.

25. McCarthy KD, de Vellis J: Preparation of separate astroglial and oligodendroglial cell cultures from rat cerebral tissue. J Cell Biol 1980, 85:890-902.

26. Dyer CA, Benjamins JA: Antibody to galactocerebroside alters organization of oligodendroglial membrane sheets in culture. J Neurosci 1988, 8:4307-4318.

27. Lisak RP, Bealmear B, Nedelkoska L, Benjamins JA: Secretory products of central nervous system glial cells induce Schwann cell proliferation and protect from cytokine-mediated death. J Neurosci Res 2006, 83:1425-I43I.

28. Raff MC, Mirsky R, Fields KL, Lisak RP, Dorfman SH, Silberberg DH, Gregson NA, Leibowitz S, Kennedy MC: Galactocerebroside is a specific cell-surface antigenic marker for oligodendrocytes in culture. Nature 1978, 274:813-816.

29. Ranchst B, Clapshaw PA, Price J, Noble M, Seifert W: Development of oligodendrocytes with a monoclonal antibody against galactocerebroside. Proc Natl Acad Sci USA 1982, 79:2709-27I3.

30. Eisenbarth GS, Walsh FS, Nirenberg M: Monoclonal antibody to a plasma membrane antigen of neurons. Proc Natl Acad Sci USA 1979, 76:49|3-4917.

31. Dijkstra CD, Van Vliet E, Dopp EA, Lelij AA van der, Kraal G: Marginal zone macrophages identified by a monoclonal antibody: characterization of immuno- and enzymehistochemical properties and functional capacities. Immunology 1985, 55:23-30.

32. Mirsky R, Thompson EJ: Thy I (theta) antigen on the surface of morphologically distinct brain cell types. Cell 1975, 4:95-I0I.

33. Pruss RM: Thy-I antigen on astrocytes in long-term cultures of rat central nervous system. Nature 1979, 280:688-690.

34. Sternberger LA, Harwell LW, Sternberger NH: Neurotypy: regional individuality in rat brain detected by immunocytochemistry with monoclonal antibodies. Proc Natl Acad Sci USA 1982, 79:1326-1330. 
35. Kim HJ, Ifergan I, Antel JP, Seguin R, Duddy M, Lapierre Y, Jalili F, BarOr A: Type 2 monocyte and microglia differentiation mediated by glatiramer acetate therapy in patients with multiple sclerosis. J Immunol 2004, 172:7|44-7I 53.

36. Liu Y, Teige I, Birnir B, Issazadeh-Navikas S: Neuron-mediated generation of regulatory $T$ cells from encephalitogenic $T$ cells suppresses EAE. Nat Med 2006, I 2:5 |8-525.

37. Baecher-Allan C, Wolf E, Hafler DA: Functional analysis of highly defined, FACS-isolated populations of human regulatory CD4+ CD25+ T cells. Clin Immunol 2005, I I5:10-18.

38. Beg AA, Baltimore $D$ : An essential role for NF-kappaB in preventing TNF-alpha-induced cell death [see comments]. Science 1996, 274:782-784

39. Li C, Wong WH: Model-based analysis of oligonucleotide arrays: expression index computation and outlier detection. Proc Natl Acad Sci USA 200I, 98:31-36.

40. Yao B, Rakhade SN, Li Q, Ahmed S, Krauss R, Draghici S, Loeb JA: Accuracy of cDNA microarray methods to detect small gene expression changes induced by neuregulin on breast epithelial cells. BMC Bioinformatics 2004, 5:99.

41. Livak KJ, Schmittgen TD: Analysis of relative gene expression data using real-time quantitative PCR and the 2(-Delta Delta C(T)) Method. Methods 200I, 25:402-408.

42. Parpura V, Basarsky TA, Liu F, Jeftinija K, Jeftinija S, Haydon PG: Glutamate-mediated astrocyte-neuron signalling. Nature 1994, 369:744-747.

43. Lehre KP, Levy LM, Ottersen OP, Storm-Mathisen J, Danbolt NC: Differential expression of two glial glutamate transporters in the rat brain: quantitative and immunocytochemical observations. J Neurosci 1995, I5:1835-1853.

44. Porter JT, McCarthy KD: Astrocytic neurotransmitter receptors in situ and in vivo. Prog Neurobiol 1997, 5 I:439-455.

45. Biber K, Laurie DJ, Berthele A, Sommer B, Tolle TR, Gebicke-Harter PJ, van Calker D, Boddeke HW: Expression and signaling of group I metabotropic glutamate receptors in astrocytes and microglia. J Neurochem 1999, 72:167I-1680.

46. Pitt D, Nagelmeier IE, Wilson HC, Raine CS: Glutamate uptake by oligodendrocytes: Implications for excitotoxicity in multiple sclerosis. Neurology 2003, 61: I I I3-I I 20.

47. Pitt $D$, Werner $P$, Raine $C S$ : Glutamate excitotoxicity in a model of multiple sclerosis. Nat Med 2000, 6:67-70.

48. Werner P, Pitt D, Raine CS: Glutamate excitotoxicity - a mechanism for axonal damage and oligodendrocyte death in Multiple Sclerosis? J Neural Transm Suppl 2000, 60:375-385.

49. Werner P, Pitt D, Raine CS: Multiple sclerosis: altered glutamate homeostasis in lesions correlates with oligodendrocyte and axonal damage. Ann Neurol 200I, 50:169-180.

50. Takahashi JL, Giuliani F, Power C, Imai Y, Yong VW: InterleukinI beta promotes oligodendrocyte death through glutamate excitotoxicity. Ann Neurol 2003, 53:588-595.

5I. Flor PJ, Battaglia G, Nicoletti F, Gasparini F, Bruno V: Neuroprotective activity of metabotropic glutamate receptor ligands. Adv Exp Med Biol 2002, 5 I 3: 1 97-223.

52. Matute C, Sanchez-Gomez MV, Martinez-Millan L, Miledi R: Glutamate receptor-mediated toxicity in optic nerve oligodendrocytes. Proc Natl Acad Sci USA 1997, 94:8830-8835.

53. Matute C, Alberdi E, Domercq M, Perez-Cerda F, Perez-Samartin A, Sanchez-Gomez MV: The link between excitotoxic oligodendroglial death and demyelinating diseases. Trends Neurosci 2001, 24:224-230.

54. Matute $C$, Perez-Cerda F: Multiple sclerosis: novel perspectives on newly forming lesions. Trends Neurosci 2005, 28: I73-I75.

55. Alberdi E, Sanchez-Gomez MV, Torre I, Domercq M, Perez-Samartin A, Perez-Cerda F, Matute C: Activation of kainate receptors sensitizes oligodendrocytes to complement attack. J Neurosci 2006, 26:3220-3228.

56. Sanchez-Gomez MV, Matute C: AMPA and kainate receptors each mediate excitotoxicity in oligodendroglial cultures. Neurobiol Dis 1999, 6:475-485.

57. McDonald JW, Althomsons SP, Hyrc KL, Choi DW, Goldberg MP. Oligodendrocytes from forebrain are highly vulnerable to AMPA/kainate receptor-mediated excitotoxicity. Nat Med 1998, 4:29|-297.

58. Geurts J], Wolswijk G, Bo L, Valk P Van Der, Polman CH, Troost D, Aronica E: Altered expression patterns of group I and II metabotropic glutamate receptors in multiple sclerosis. Brain 2003, I 26: 1755-1766.

59. Ankarcrona M, Dypbukt JM, Bonfoco E, Zhivotovsky B, Orrenius S, Lipton SA, Nicotera P: Glutamate-induced neuronal death: a succession of necrosis or apoptosis depending on mitochondrial function. Neuron 1995, 15:961-973.

60. Castiglione M, Mangano K, Busceti CL, Nicoletti FR, et al.: Activation of group III metabotropic glutamate receptors inhibits the production of RANTES in glial cell cultures. I Neurosci 2002, 22:5403-54II.

61. Abbracchio MP, Burnstock G: Purinergic signalling: pathophysiological roles. Jpn J Pharmacol |998, 78: | |3-145.

62. Bianco F, Ceruti S, Colombo A, Fumagalli M, Ferrari D, Pizzirani C, Matteoli M, Di Virgilio F, Abbracchio MP, Verderio C: A role for P2X7 in microglial proliferation. J Neurochem 2006, 99:745-758.

63. Yiangou $Y$, Facer $P$, Durrenberger $P$, Chessell IP, Naylor A, Bountra C, Banati RR, Anand P: COX-2, CB2 and P2X7-immunoreactivities are increased in activated microglial cells/macrophages of multiple sclerosis and amyotrophic lateral sclerosis spinal cord. BMC Neurol 2006, 6:12.

64. Narcisse L, Scemes E, Zhao Y, Lee SC, Brosnan CF: The cytokine IL-I beta transiently enhances $P 2 X 7$ receptor expression and function in human astrocytes. Glia 2005, 49:245-258.

65. Wang $Y$, Roman R, Lidofsky SD, Fitz JG: Autocrine signaling through ATP release represents a novel mechanism for cell volume regulation. Proc Natl Acad Sci USA 1996, 93: I 2020-I 2025.

66. Rappold PM, Lynd-Balta E, Joseph SA: P2X7 receptor immunoreactive profile confined to resting and activated microglia in the epileptic brain. Brain Res 2006, I089:I7I-I78.

67. Bongarzone ER, Howard SG, Schonmann V, Campagnoni AT: Identification of the dopamine D3 receptor in oligodendrocyte precursors: potential role in regulating differentiation and myelin formation. J Neurosci 1998, 18:5344-5353.

68. Rosin C, Colombo S, Calver AA, Bates TE, Skaper SD: Dopamine D2 and D3 receptor agonists limit oligodendrocyte injury caused by glutamate oxidative stress and oxygen/glucose deprivation. Glia 2005, 52:336-343.

69. Wang H, Yu M, Ochani M, Amella CA, Tanovic M, Susarla S, Li JH, Yang $\mathrm{H}$, Ulloa L, Al-Abed $\mathrm{Y}$, et al.: Nicotinic acetylcholine receptor alpha7 subunit is an essential regulator of inflammation. Nature 2003, 421 : 384-388.

70. Shytle RD, Mori T, Townsend K, Vendrame M, Sun N, Zeng J, Ehrhart J, Silver AA, Sanberg PR, Tan J: Cholinergic modulation of microglial activation by alpha 7 nicotinic receptors. J Neurochem 2004, 89:337-343.

7I. Nizri E, Hamra-Amitay Y, Sicsic C, Lavon I, Brenner T: Anti-inflammatory properties of cholinergic up-regulation: A new role for acetylcholinesterase inhibitors. Neuropharmacology 2006, 50:540-547.

72. Burghaus L, Schutz U, Krempel U, Lindstrom J, Schroder H: Loss of nicotinic acetylcholine receptor subunits alpha4 and alpha7 in the cerebral cortex of Parkinson patients. Parkinsonism Relat Disord 2003, 9:243-246.

73. Soliven B, Szuchet S, Arnason BG, Nelson DJ: Expression and modulation of $\mathrm{K}+$ currents in oligodendrocytes: possible role in myelinogenesis. Dev Neurosci 1989, I I: | | 8-I31.

74. Black JA, Westenbroek R, Minturn JE, Ransom BR, Catterall WA, Waxman SG: soform-specific expression of sodium channels in astrocytes in vitro: immunocytochemical observations. Glia 1995, 14:1/33-144.

75. Visentin S, Levi G: Protein kinase $\mathbf{C}$ involvement in the resting and interferon-gamma-induced $\mathrm{K}+$ channel profile of microglial cells. J Neurosci Res 1997, 47:233-24I.

76. Attali B, Wang N, Kolot A, Sobko A, Cherepanov V, Soliven B: Characterization of delayed rectifier $\mathrm{Kv}$ channels in oligodendrocytes and progenitor cells. J Neurosci 1997, 17:8234-8245.

77. Verkhratsky A, Steinhauser C: Ion channels in glial cells. Brain Res Brain Res Rev 2000, 32:380-412.

78. Soliven B, Szuchet S, Nelson D: Tumor necrosis factor inhibits $\mathrm{K}^{+}$current expression in cultured oligodendrocytes. J Membr Biol 1991, 124:127-137.

79. Cameron JS, Lhuillier L, Subramony P, Dryer SE: Developmental regulation of neuronal $\mathrm{K}+$ channels by target-derived TGF beta in vivo and in vitro. Neuron 1998, 21:1045-1053. 
80. Iwagaki H, Fuchimoto S, Miyake M, Aoki H, Orita K: Interferongamma activates the voltage-gated calcium channel in RPMI 4788 cells. Biochem Biophys Res Commun 1988, I 53:|276-I28I.

81. Norenberg W, Gebicke-Haerter PJ, Illes P: Inflammatory stimuli induce a new $\mathrm{K}+$ outward current in cultured rat microglia. Neurosci Lett 1992, I47:I71-I74.

82. Smith KJ, McDonald WI: The pathophysiology of multiple sclerosis: the mechanisms underlying the production of symptoms and the natural history of the disease. Philos Trans $R$ Soc Lond B Biol Sci 1999, 354: I649-1673.

83. Smith KJ, Hall SM: Factors directly affecting impulse transmission in inflammatory demyelinating disease: recent advances in our understanding. Curr Opin Neurol 200I, I 4:289-298.

84. Smith KJ, Kapoor R, Hall SM, Davies M: Electrically active axons degenerate when exposed to nitric oxide. Ann Neurol 200I, 49:470-476

85. Waxman SG: Nitric oxide and the axonal death cascade. Ann Neurol 2003, 53:150-153.

86. Craner MJ, Lo AC, Black JA, Waxman SG: Abnormal sodium channel distribution in optic nerve axons in a model of inflammatory demyelination. Brain 2003, I26: |552-|56| .

87. Carmody RJ, Hilliard B, Maguschak K, Chodosh LA, Chen YH: Genomic scale profiling of autoimmune inflammation in the central nervous system: the nervous response to inflammation. J Neuroimmunol 2002, I 33:95-107.

88. Kapoor R, Davies M, Blaker PA, Hall SM, Smith KJ: Blockers of sodium and calcium entry protect axons from nitric oxidemediated degeneration. Ann Neurol 2003, 53:174-180.

89. Stys PK: General mechanisms of axonal damage and its prevention. J Neurol Sci 2005, 233:3-I3.

90. Stys PK, Waxman SG, Ransom BR: Na(+)-Ca2+ exchanger mediates $\mathrm{Ca2+}$ influx during anoxia in mammalian central nervous system white matter. Ann Neurol 1991, 30:375-380.

91. Kalman B, Leist TP: A mitochondrial component of neurodegeneration in multiple sclerosis. Neuromolecular Med 2003, 3:147-158.

92. Wulff $\mathrm{H}$, Calabresi PA, Allie $\mathrm{R}$, Yun S, Pennington M, Beeton C, Chandy KG: The voltage-gated KvI.3 K(+) channel in effector memory T cells as new target for MS. J Clin Invest 2003 I I I:I703-17|3.

93. Gu C, Casaccia-Bonnefil P, Srinivasan A, Chao MV: Oligodendrocyte apoptosis mediated by caspase activation. I Neurosci 1999, 19:3043-3049.

94. Bredesen DE, Mehlen P, Rabizadeh S: Apoptosis and dependence receptors: a molecular basis for cellular addiction. Physiol Rev 2004, 84:4II -430.

95. Lucchinetti C, Bruck W, Parisi J, Scheithauer B, Rodriguez M, Lassmann H: Heterogeneity of multiple sclerosis lesions: implications for the pathogenesis of demyelination [see comments]. Ann Neurol 2000, 47:707-7I7.

96. Peterson JW, Bo L, Mork S, Chang A, Trapp BD: Transected neurites, apoptotic neurons, and reduced inflammation in cortical multiple sclerosis lesions. Ann Neurol 200I, 50:389-400.

97. Tomita Y, Bilim V, Hara N, Kasahara T, Takahashi K: Role of IRF-I and caspase-7 in IFN-gamma enhancement of Fas-mediated apoptosis in ACHN renal cell carcinoma cells. Int J Cancer 2003, 1 04:400-408.

98. Gross A, McDonnell JM, Korsmeyer SJ: BCL-2 family members and the mitochondria in apoptosis. Genes Dev 1999, 13:1899-1911.

99. Gross A, Yin XM, Wang K, Wei MC, Jockel J, Milliman C, ErdjumentBromage H, Tempst P, Korsmeyer SJ: Caspase cleaved BID targets mitochondria and is required for cytochrome $c$ release, while BCL-XL prevents this release but not tumor necrosis factor-RI/Fas death. I Biol Chem 1999, 274: I I 56-I I63.

100. Rigamonti D, Sipione S, Goffredo D, Zuccato C, Fossale E, Cattaneo $\mathrm{E}$ : Huntingtin's neuroprotective activity occurs via inhibition of procaspase-9 processing. J Biol Chem 200I, 276: I 4545-| 4548

101. Gervais FG, Singaraja R, Xanthoudakis S, Gutekunst CA, Leavitt BR, Metzler M, Hackam AS, Tam J, Vaillancourt JP, Houtzager V, et al.: Recruitment and activation of caspase- 8 by the Huntingtininteracting protein Hip-I and a novel partner Hippi. Nat Cell Biol 2002, 4:95-105.

102. Engqvist-Goldstein AE, Warren RA, Kessels MM, Keen JH, Heuser J, Drubin DG: The actin-binding protein Hip I R associates with clathrin during early stages of endocytosis and promotes clathrin assembly in vitro. J Cell Biol 200I, I 54: I 209-I223.

103. Harjes $P$, Wanker EE: The hunt for huntingtin function: interaction partners tell many different stories. Trends Biochem Sci 2003, 28:425-433.

104. Bence NF, Sampat RM, Kopito RR: Impairment of the ubiquitinproteasome system by protein aggregation. Science 200I, 292: I552-1555.

105. Sharma MR, Koc EC, Datta PP, Booth TM, Spremulli LL, Agrawal RK: Structure of the mammalian mitochondrial ribosome reveals an expanded functional role for its component proteins. Cell 2003, I 15:97-108.

106. Kunst CB, Mezey E, Brownstein MJ, Patterson D: Mutations in SODI associated with amyotrophic lateral sclerosis cause novel protein interactions. Nat Genet 1997, I 5:91-94.

107. Dringen R, Kussmaul L, Gutterer JM, Hirrlinger J, Hamprecht B: The glutathione system of peroxide detoxification is less efficient in neurons than in astroglial cells. I Neurochem 1999, 72:2523-2530.

108. Baud O, Greene AE, Li J, Wang H, Volpe J, Rosenberg PA: Glutathione peroxidase-catalase cooperativity is required for resistance to hydrogen peroxide by mature rat oligodendrocytes. | Neurosci 2004, 24:|53|-1540.

109. Hirrlinger J, Konig J, Dringen R: Expression of mRNAs of multidrug resistance proteins (Mrps) in cultured rat astrocytes, oligodendrocytes, microglial cells and neurones. I Neurochem 2002, 82:716-719.

I I0. Hirrlinger J, Konig J, Keppler D, Lindenau J, Schulz JB, Dringen R: The multidrug resistance protein MRPI mediates the release of glutathione disulfide from rat astrocytes during oxidative stress. I Neurochem 200I, 76:627-636.

III. Volk H, Potschka H, Loscher W: Immunohistochemical localization of $\mathbf{P}$-glycoprotein in rat brain and detection of its increased expression by seizures are sensitive to fixation and staining variables. J Histochem Cytochem 2005, 53:5 I7-53I.

I 12. Volk HA, Burkhardt K, Potschka H, Chen J, Becker A, Loscher W: Neuronal expression of the drug efflux transporter P-glycoprotein in the rat hippocampus after limbic seizures. Neuroscience 2004, I 23:751-759.

I 13. Volk HA, Loscher W: Multidrug resistance in epilepsy: rats with drug-resistant seizures exhibit enhanced brain expression of $P$-glycoprotein compared with rats with drug-responsive seizures. Brain 2005, I 28: | 358-1368.

II4. Juurlink BH: Response of glial cells to ischemia: roles of reactive oxygen species and glutathione. Neurosci Biobehav Rev 1997. 2I:|15|-166.

I I5. Barker JE, Bolanos JP, Land JM, Clark JB, Heales SJ: Glutathione protects astrocytes from peroxynitrite-mediated mitochondrial damage: implications for neuronal/astrocytic trafficking and neurodegeneration. Dev Neurosci 1996, I 8:391-396.

I 16. Back SA, Gan X, Li Y, Rosenberg PA, Volpe J]: Maturation-dependent vulnerability of oligodendrocytes to oxidative stressinduced death caused by glutathione depletion. I Neurosci 1998, 18:6241-6253.

I17. Margalit A, Hauser SD, Zweifel BS, Anderson MA, Isakson PC: Regulation of prostaglandin biosynthesis in vivo by glutathione. Am J Physiol 1998, 274:R294-302.

I 18. Götschel F, Kern C, Lang S, Sparna T, Markmann C, Schwager J, McNelly S, von Weizsäcker F, Laufer S, Hecht A, Merfort I: Inhibition of GSK3 differentially modulates NF-kappaB, CREB, AP-I and beta-catenin signaling in hepatocytes, but fails to promote TNF-alpha-induced apoptosis. Exp Cell Res 2008, 3 | 4: $135 \mid-66$

119. John GR, Shankar SL, Shafit-Zagardo B, Massimi A, Lee SC, Raine CS, Brosnan CF: Multiple sclerosis: Re-expression of a developmental pathway that restricts oligodendrocyte maturation. Nat Med 2002, 8: III5-II2I.

120. Stidworthy MF, Genoud S, Li WW, Leone DP, Mantei N, Suter U, Franklin RJ: Notch I and Jagged I are expressed after CNS demyelination, but are not a major rate-determining factor during remyelination. Brain 2004, I 27: | 928- I94 I.

121. Cimini A, Bernardo A, Cifone G, Di Muzio L, Di Loreto S: TNFalpha downregulates PPARdelta expression in oligodendrocyte progenitor cells: implications for demyelinating diseases. Glia 2003, 41:3-14. 
122. Feinstein DL, Galea E, Gavrilyuk V, Brosnan CF, Whitacre CC, Dumitrescu-Ozimek L, Landreth GE, Pershadsingh HA, Weinberg G, Heneka MT: Peroxisome proliferator-activated receptorgamma agonists prevent experimental autoimmune encephalomyelitis. Ann Neurol 2002, 5 I:694-702.

123. Natarajan C, Bright J]: Peroxisome proliferator-activated receptor-gamma agonists inhibit experimental allergic encephalomyelitis by blocking IL- I 2 production, IL- I 2 signaling and Th I differentiation. Genes Immun 2002, 3:59-70.

124. Saluja I, Granneman JG, Skoff RP: PPAR delta agonists stimulate oligodendrocyte differentiation in tissue culture. Glia 200I, 33: $191-204$.

125. Satriotomo I, Bowen KK, Vemuganti R: JAK2 and STAT3 activation contributes to neuronal damage following transient focal cerebral ischemia. I Neurochem 2006, 98: I353-I368.

126. Tajouri L, Mellick AS, Tourtellotte A, Nagra RM, Griffiths LR: An examination of MS candidate genes identified as differentially regulated in multiple sclerosis plaque tissue, using absolute and comparative real-time Q-PCR analysis. Brain Res Brain Res Protoc 2005, I 5:79-9I.

127. Xiao B, Tu JC, Worley PF: Homer: a link between neural activity and glutamate receptor function. Curr Opin Neurobiol 2000, 10:370-374.

128. Rong R, Ahn JY, Huang H, Nagata E, Kalman D, Kapp JA, Tu J, Worley PF, Snyder SH, Ye K: PI3 kinase enhancer-Homer complex couples mGluRI to PI3 kinase, preventing neuronal apoptosis. Nat Neurosci 2003, 6: II53-II6I.

129. Roche KW, Tu JC, Petralia RS, Xiao B, Wenthold RJ, Worley PF: Homer I b regulates the trafficking of group I metabotropic glutamate receptors. J Biol Chem 1999, 274:25953-25957.

130. Ango F, Robbe D, Tu JC, Xiao B, Worley PF, Pin JP, Bockaert J, Fagni $L$ : Homer-dependent cell surface expression of metabotropic glutamate receptor type 5 in neurons. Mol Cell Neurosci 2002, 20:323-329.

I3I. Osterhout DJ, Wolven A, Wolf RM, Resh MD, Chao MV: Morphological differentiation of oligodendrocytes requires activation of Fyn tyrosine kinase. J Cell Biol 1999, I45:|209-I2I8.

132. Liang $X$, Draghi NA, Resh MD: Signaling from integrins to Fyn to Rho family GTPases regulates morphologic differentiation of oligodendrocytes. J Neurosci 2004, 24:7|40-7|49.

133. Galvin JE, Lee VM, Trojanowski JQ: Synucleinopathies: clinical and pathological implications. Arch Neurol 200I, 58: I86-190.

134. Cooper AA, Gitler AD, Cashikar A, Haynes CM, Hill KJ, Bhullar B, Liu K, Xu K, Strathearn KE, Liu F, et al.: \{alpha\}-Synuclein Blocks ERGolgi Traffic and Rab I Rescues Neuron Loss in Parkinson's Models. Science 2006, 3 1 3:324-328.

135. Kaplan B, Ratner V, Haas E: Alpha-synuclein: its biological function and role in neurodegenerative diseases. I Mol Neurosci 2003, 20:83-92.

136. Lee D, Paik SR, Choi KY: Beta-synuclein exhibits chaperone activity more efficiently than alpha-synuclein. FEBS Lett 2004, 576:256-260.

137. Richter-Landsberg C, Gorath M, Trojanowski JQ, Lee VM: alphasynuclein is developmentally expressed in cultured rat brain oligodendrocytes. J Neurosci Res 2000, 62:9-I4.

138. Piao YS, Mori F, Hayashi S, Tanji K, Yoshimoto M, Kakita A, Wakabayashi K, Takahashi H: Alpha-synuclein pathology affecting Bergmann glia of the cerebellum in patients with alphasynucleinopathies. Acta Neuropathol 2003, I 05(4):403-409.

139. Brosnan CF, Battistini L, Gao YL, Raine CS, Aquino DA: Heat shock proteins and multiple sclerosis: a review. J Neuropathol Exp Neurol 1996, 55:389-402.

140. Stuve O, Prod'homme T, Slavin A, Youssef S, Dunn S, Steinman L, Zamvil SS: Statins and their potential targets in multiple sclerosis therapy. Expert Opin Ther Targets 2003, 7:613-622.

141. Neuhaus O, Stuve O, Archelos JJ, Hartung HP: Putative mechanisms of action of statins in multiple sclerosis - comparison to interferon-beta and glatiramer acetate. J Neurol Sci 2005, 233: $173-177$.

142. Weber MS, Youssef S, Dunn SE, Prod'homme T, Neuhaus O, Stuve O, Greenwood J, Steinman L, Zamvil SS: Statins in the treatment of central nervous system autoimmune disease. J Neuroimmunol 2006, I 78: |40-148.

143. Youssef S, Stuve O, Patarroyo JC, Ruiz PJ, Radosevich JL, Hur EM, Bravo M, Mitchell DJ, Sobel RA, Steinman L, Zamvil SS: The HMGCoA reductase inhibitor, atorvastatin, promotes a Th2 bias and reverses paralysis in central nervous system autoimmune disease. Nature 2002, 420:78-84.

144. Nath N, Giri S, Prasad R, Singh AK, Singh I: Potential targets of 3hydroxy-3-methylglutaryl coenzyme $A$ reductase inhibitor for multiple sclerosis therapy. J Immunol 2004, I 72: I 273-I 286.

145. Greenwood J, Walters CE, Pryce G, Kanuga N, Beraud E, Baker D, Adamson P: Lovastatin inhibits brain endothelial cell Rhomediated lymphocyte migration and attenuates experimental autoimmune encephalomyelitis. Faseb / 2003, 1 7:905-907.

146. Gong JS, Kobayashi M, Hayashi H, Zou K, Sawamura N, Fujita SC, Yanagisawa K, Michikawa M: Apolipoprotein E (ApoE) isoformdependent lipid release from astrocytes prepared from human ApoE3 and ApoE4 knock-in mice. J Biol Chem 2002, 277:29919-29926.

147. Tanaka Y, Yamada K, Zhou CJ, Ban N, Shioda S, Inagaki N: Temporal and spatial profiles of ABCA2-expressing oligodendrocytes in the developing rat brain. J Comp Neurol 2003, 455:353-367.

148. Chakraborty G, Reddy R, Drivas A, Ledeen RW: Interleukin-2 receptors and interleukin-2-mediated signaling in myelin: activation of diacylglycerol kinase and phosphatidylinositol 3-kinase. Neuroscience 2003, I 22:967-973.

149. Sarkar S, Floto RA, Berger Z, Imarisio S, Cordenier A, Pasco M, Cook L], Rubinsztein DC: Lithium induces autophagy by inhibiting inositol monophosphatase. J Cell Biol 2005, I 70: I I0I-I I II.

150. Bedlack RS, Maragakis N, Heiman-Patterson T: Lithium may slow progression of amyotrophic lateral sclerosis, but further study is needed. Proc Natl Acad Sci USA 2008, I05:E I7. author reply El8

15I. Fornai F, Longone P, Ferrucci M, Lenzi P, Isidoro C, Ruggieri S, Paparelli A: he multiple roles of lithium. Autophagy 2008, 4:T527-530.

152. Fornai F, Longone P, Cafaro L, Kastsiuchenka O, Ferrucci M, Manca ML, Lazzeri G, Spalloni A, Bellio N, Lenzi P, et al.: Lithium delays progression of amyotrophic lateral sclerosis. Proc Natl Acad Sci USA 2008, 105:2052-2057.

153. Chalfant CE, Spiegel S: Sphingosine I-phosphate and ceramide I-phosphate: expanding roles in cell signaling. J Cell Sci 2005, I 1 8:4605-46। 2

154. Kappos L, Antel J, Comi G, Montalban X, O'Connor P, Polman CH, Haas T, Korn AA, Karlsson G, Radue EW: Oral fingolimod (FTY720) for relapsing multiple sclerosis. N Engl J Med 2006, 355: II24-I | 40.

I55. Singer II, Tian M, Wickham LA, Lin J, Matheravidathu SS, Forrest MJ, Mandala S, Quackenbush EJ: Sphingosine-I-phosphate agonists increase macrophage homing, lymphocyte contacts, and endothelial junctional complex formation in murine lymph nodes. J Immunol 2005, I 75:7| 5I-7|6I.

156. Yopp AC, Ochando JC, Mao M, Ledgerwood L, Ding Y, Bromberg JS: Sphingosine I-phosphate receptors regulate chemokinedriven transendothelial migration of lymph node but not splenic T cells. J Immunol 2005, I 75:2913-2924.

157. Lee MJ, Van Brocklyn JR, Thangada S, Liu CH, Hand AR, Menzeleev R, Spiegel S, Hla T: Sphingosine-I-phosphate as a ligand for the G protein-coupled receptor EDG-I. Science 1998, 279: I 552-I 555.

158. Hla T: Signaling and biological actions of sphingosine I-phosphate. Pharmacol Res 2003, 47:40 I-407.

159. Czeloth N, Bernhardt G, Hofmann F, Genth H, Forster R: Sphingosine-I-phosphate mediates migration of mature dendritic cells. J Immunol 2005, I 75:2960-2967.

160. Cyster JG: Chemokines, sphingosine-I-phosphate, and cell migration in secondary lymphoid organs. Annu Rev Immunol 2005, 23:127-159.

16I. Toman RE, Spiegel S: Lysophospholipid receptors in the nervous system. Neurochem Res 2002, 27:619-627.

162. Hida H, Nagano S, Takeda M, Soliven B: Regulation of mitogenactivated protein kinases by sphingolipid products in oligodendrocytes. J Neurosci 1999, 19:7458-7467.

163. Pebay A, Toutant M, Premont J, Calvo CF, Venance L, Cordier J, Glowinski J, Tence M: Sphingosine-I-phosphate induces proliferation of astrocytes: regulation by intracellular signalling cascades. Eur J Neurosci 200I, I 3:2067-2076.

164. Mullershausen F, Craveiro LM, Shin Y, Cortes-Cros M, Bassilana F, Osinde M, Wishart WL, Guerini D, Thallmair M, Schwab ME, et al.: Phosphorylated FTY720 promotes astrocyte migration through sphingosine-I-phosphate receptors. I Neurochem 2007, 102:||5|-||6|. 
165. Miron VE, Jung CG, Kim HJ, Kennedy TE, Soliven B, Antel JP: FTY720 modulates human oligodendrocyte progenitor process extension and survival. Ann Neurol 2008, 63:6l-7I.

166. Ebert R, Schutze N, Adamski J, Jakob F: Vitamin D signaling is modulated on multiple levels in health and disease. Mol Cell Endocrinol 2006, 248: I49-I59.

167. Spach KM, Pedersen LB, Nashold FE, Kayo T, Yandell BS, Prolla TA, Hayes CE: Gene expression analysis suggests that I,25-dihydroxyvitamin D3 reverses experimental autoimmune encephalomyelitis by stimulating inflammatory cell apoptosis. Physiol Genomics 2004, I 8: |4I-I5I.

168. Munger KL, Zhang SM, O'Reilly E, Hernan MA, Olek MJ, Willett WC, Ascherio A: Vitamin D intake and incidence of multiple sclerosis. Neurology 2004, 62:60-65.

169. Brown S]: The role of vitamin $\mathbf{D}$ in multiple sclerosis. Ann Pharmacother 2006, 40: I I58-I I6I.

170. Brosnan CF, Battistini L, Raine CS, Dickson DW, Casadevall A, Lee SC: Reactive nitrogen intermediates in human neuropathology: an overview. Dev Neurosci 1994, 16:152-I6II.

17I. Smith KJ, Lassmann $\mathrm{H}$ : The role of nitric oxide in multiple sclerosis. Lancet Neurol 2002, I:232-24I.

172. Zhang J, Cross AH, McCarthy TJ, Welch MJ: Measurement of upregulation of inducible nitric oxide synthase in the experimental autoimmune encephalomyelitis model using a positron emitting radiopharmaceutical. Nitric Oxide 1997, I:263-267.

173. Bagasra O, Michaels FH, Zheng YM, Bobroski LE, Spitsin SV, Fu ZF, Tawadros R, Koprowski $\mathrm{H}$ : Activation of the inducible form of nitric oxide synthase in the brains of patients with multiple sclerosis. Proc Natl Acad Sci USA 1995, 92: | 204 I- I 2045.

174. Hill KE, Zollinger LV, Watt HE, Carlson NG, Rose JW: Inducible nitric oxide synthase in chronic active multiple sclerosis plaques: distribution, cellular expression and association with myelin damage. I Neuroimmunol 2004, I 5 I: | 7 | - I79.

175. Boullerne Al, Benjamins JA: Nitric oxide synthase expression and nitric oxide toxicity in oligodendrocytes. Antioxid Redox Signal 2006, 8:967-980. Review

176. Waxman SG, Craner MJ, Black JA: Na+ channel expression along axons in multiple sclerosis and its models. Trends Pharmacol Sci 2004, 25:584-59.

177. Hokfelt T, Wiesenfeld-Hallin Z, Villar M, Melander T: Increase of galanin-like immunoreactivity in rat dorsal root ganglion cells after peripheral axotomy. Neurosci Lett 1987, 83:217-220.

178. Kashiba H, Senba E, Kawai Y, Ueda Y, Tohyama M: Axonal blockade induces the expression of vasoactive intestinal polypeptide and galanin in rat dorsal root ganglion neurons. Brain Res 1992, 577:19-28.

179. Shen PJ, Larm JA, Gundlach AL: Expression and plasticity of galanin systems in cortical neurons, oligodendrocyte progenitors and proliferative zones in normal brain and after spreading depression. Eur J Neurosci 2003, I 8: |362-1376.

180. Ubink R, Calza L, Hokfelt T: 'Neuro'-peptides in glia: focus on NPY and galanin. Trends Neurosci 2003, 26:604-609.

18I. Holmes FE, Mahoney S, King VR, Bacon A, Kerr NC, Pachnis V, Curtis $\mathrm{R}$, Priestley JV, Wynick D: Targeted disruption of the galanin gene reduces the number of sensory neurons and their regenerative capacity. Proc Natl Acad Sci USA 2000 97: II563-II568.

182. Mahoney SA, Hosking R, Farrant S, Holmes FE, Jacoby AS, Shine J, lismaa TP, Scott MK, Schmidt R, Wynick D: The second galanin receptor GaIR2 plays a key role in neurite outgrowth from adult sensory neurons. J Neurosci 2003, 23:4I6-42I.

183. O'Meara G, Coumis U, Ma SY, Kehr J, Mahoney S, Bacon A, Allen SJ, Holmes F, Kahl U, Wang FH, et al: Galanin regulates the postnatal survival of a subset of basal forebrain cholinergic neurons. Proc Natl Acad Sci USA 2000, 97: I I569-I I 574.

184. Sahu $A, X u B$, Kalra SP: Role of galanin in stimulation of pituitary luteinizing hormone secretion as revealed by a specific receptor antagonist, galantide. Endocrinology 1994, 134:529-536.

185. Wynick D, Small C], Bacon A, Holmes FE, Norman M, Ormandy CI Kilic E, Kerr NC, Ghatei M, Talamantes F, et al.: Galanin regulates prolactin release and lactotroph proliferation. Proc Natl Acad Sci USA 1998, 95: | 267|-12676.

186. Holmes FE, Bacon A, Pope RJ, Vanderplank PA, Kerr NC, Sukumaran $M$, Pachnis $V$, Wynick $D$ : Transgenic overexpression of galanin in the dorsal root ganglia modulates pain-related behavior. Proc Natl Acad Sci USA 2003, I 00:6180-6185.

187. Wiesenfeld-Hallin Z, Xu XJ, Villar MJ, Hokfelt T: Intrathecal galanin potentiates the spinal analgesic effect of morphine: electrophysiological and behavioural studies. Neurosci Lett 1990, 109:217-221.

188. Nordstrom O, Melander T, Hokfelt T, Bartfai T, Goldstein M: Evidence for an inhibitory effect of the peptide galanin on dopamine release from the rat median eminence. Neurosci Lett 1987, 73:21-26.

189. Sundstrom E, Archer T, Melander T, Hokfelt T: Galanin impairs acquisition but not retrieval of spatial memory in rats studied in the Morris swim maze. Neurosci Lett 1988, 88:33I-335.

190. Hosli E, Ledergerber M, Kofler A, Hosli L: Evidence for the existence of galanin receptors on cultured astrocytes of rat CNS: colocalization with cholinergic receptors. J Chem Neuroanat 1997, 13:95-103.

191. Dugas JC, Tai YC, Speed TP, Ngai J, Barres BA: Functional genomic analysis of oligodendrocyte differentiation. J Neurosci 2006 , 26:10967-10983

192. Brenner T, Abramsky O: Immunosuppression of experimental autoimmune myasthenia gravis by alpha-fetoprotein rich formation. Immunol Lett |98I, 3:I63-I67.

193. Lubetzki-Korn I, Hirayama M, Silberberg DH, Schreiber AD, Eccleston PA, Pleasure D, Brenner T, Abramsky O: Human alpha-fetoprotein-rich fraction inhibits galactocerebroside antibodymediated lysis of oligodendrocytes in vitro. Ann Neurol 1984, I5:171-180.

194. Evron S, Brenner T, Abramsky O: Suppressive effect of pregnancy on the development of experimental allergic encephalomyelitis in rabbits. Am / Reprod Immunol 1984, 5: 109-1 I3.

195. Brenner T, Evron S, Soffer D, Abramsky O: Treatment of experimental allergic encephalomyelitis in rabbits with alpha-fetoprotein. Isr J Med Sci 1985, 21:945-949.

196. Sanchez-Ramos J, Song S, Cardozo-Pelaez F, Hazzi C, Stedeford T, Willing A, Freeman TB, Saporta S, Janssen W, Patel N, et al.: Adult bone marrow stromal cells differentiate into neural cells in vitro. Exp Neurol 2000, 164:247-256.

197. Gallo V, Armstrong RC: Developmental and growth factorinduced regulation of nestin in oligodendrocyte lineage cells. J Neurosci 1995, I 5:394-406.

198. Filippov V, Kronenberg G, Pivneva T, Reuter K, Steiner B, Wang LP, Yamaguchi M, Kettenmann H, Kempermann G: Subpopulation of nestin-expressing progenitor cells in the adult murine hippocampus shows electrophysiological and morphological characteristics of astrocytes. Mol Cell Neurosci 2003, 23:373-382.

199. Almazan G, Vela JM, Molina-Holgado E, Guaza C: Re-evaluation of nestin as a marker of oligodendrocyte lineage cells. Microsc Res Tech 200I, 52:753-765.

200. Brenneman DE, Phillips TM, Hauser J, Hill JM, Spong CY, Gozes I: Complex array of cytokines released by vasoactive intestinal peptide. Neuropeptides 2003, 37:III-II9.

201. Gozes I, Brenneman DE: A new concept in the pharmacology of neuroprotection. J Mol Neurosci 2000, I 4:6I-68.

202. Wu L, Iwai M, Li Z, Shiuchi T, Min LJ, Cui TX, Li JM, Okumura M, Nahmias C, Horiuchi M: Regulation of inhibitory protein-kappaB and monocyte chemoattractant protein-I by angiotensin II type 2 receptor-activated Src homology protein tyrosine phosphatase-I in fetal vascular smooth muscle cells. Mol Endocrinol 2004, I 8:666-678.

203. Zhang X, Lassila M, Cooper ME, Cao Z: Retinal expression of vascular endothelial growth factor is mediated by angiotensin type I and type 2 receptors. Hypertension 2004, 43:276-28I.

204. Sarlos S, Rizkalla B, Moravski C], Cao Z, Cooper ME, Wilkinson-Berka JL: Retinal angiogenesis is mediated by an interaction between the angiotensin type 2 receptor, VEGF, and angiopoietin. Am J Pathol 2003, I 63:879-887.

205. Steinman L, Zamvil S: Transcriptional analysis of targets in multiple sclerosis. Nat Rev Immunol 2003, 3:483-492.

206. Steinman L: Gene microarrays and experimental demyelinating disease: a tool to enhance serendipity. Brain 200I, 124:1897-1899.

207. Passafaro M, Sala C, Niethammer M, Sheng M: Microtubule binding by CRIPT and its potential role in the synaptic clustering of PSD-95. Nat Neurosci 1999, 2:1063-1069. 
208. Fukaya M, Watanabe M: Improved immunohistochemical detection of postsynaptically located PSD-95/SAP90 protein family by protease section pretreatment: a study in the adult mouse brain. J Comp Neurol 2000, 426:572-586.

209. Klomp LW, Gitlin JD: Expression of the ceruloplasmin gene in the human retina and brain: implications for a pathogenic model in aceruloplasminemia. Hum Mol Genet 1996, 5:1989-1996.

210. Yoshida K, Kaneko K, Miyajima H, Tokuda T, Nakamura A, Kato M, Ikeda S: Increased lipid peroxidation in the brains of aceruloplasminemia patients. J Neurol Sci 2000, 175:9/-95.

21I. Patel BN, Dunn RJ, Jeong SY, Zhu Q, Julien JP, David S: Ceruloplasmin regulates iron levels in the CNS and prevents free radical injury. J Neurosci 2002, 22:6578-6586.

212. Shin T, Kim H, Jin JK, Moon C, Ahn M, Tanuma N, Matsumoto Y: Expression of caveolin- I, -2 , and -3 in the spinal cords of Lewis rats with experimental autoimmune encephalomyelitis. J Neuroimmunol 2005, 165: I I-20.

213. Cai D, Deng K, Mellado W, Lee J, Ratan RR, Filbin MT: Arginase I and polyamines act downstream from cyclic AMP in overcoming inhibition of axonal growth MAG and myelin in vitro. Neuron 2002, 35:7II-719.

214. Hesse M, Modolell M, La Flamme AC, Schito M, Fuentes JM, Cheever AW, Pearce EJ, Wynn TA: Differential regulation of nitric oxide synthase- 2 and arginase-I by type I/type 2 cytokines in vivo: granulomatous pathology is shaped by the pattern of Larginine metabolism. J Immunol 200I, 167:6533-6544.

215. Louis CA, Mody V, Henry WL Jr, Reichner JS, Albina JE: Regulation of arginase isoforms I and II by IL-4 in cultured murine peritoneal macrophages. Am J Physiol 1999, 276:R237-242.

216. Mori M, Gotoh T: Regulation of nitric oxide production by arginine metabolic enzymes. Biochem Biophys Res Commun 2000, 275:715-719.

217. Estevez AG, Sahawneh MA, Lange PS, Bae N, Egea M, Ratan RR: Arginase I regulation of nitric oxide production is key to survival of trophic factor-deprived motor neurons. J Neurosci 2006, 26:85I2-85I6.

218. Becker-Catania SG, Gregory TL, Yang Y, Gau CL, de Vellis J, Cederbaum SD, lyer RK: Loss of arginase I results in increased proliferation of neural stem cells. J Neurosci Res 2006, 84:735-746.

219. Lassmann H: Hypoxia-like tissue injury as a component of multiple sclerosis lesions. J Neurol Sci 2003, 206:|87-|9|.

220. Kirk SL, Karlik SJ: VEGF and vascular changes in chronic neuroinflammation. J Autoimmun 2003, 21:353-363.

Publish with Biomed Central and every scientist can read your work free of charge

"BioMed Central will be the most significant development for disseminating the results of biomedical research in our lifetime. "

Sir Paul Nurse, Cancer Research UK

Your research papers will be:

- available free of charge to the entire biomedical community

- peer reviewed and published immediately upon acceptance

- cited in PubMed and archived on PubMed Central

- yours - you keep the copyright

Submit your manuscript here:

http://www.biomedcentral.com/info/publishing_adv.asp
BioMedcentral 